\title{
How to Adapt Chemical Risk Assessment for Unconventional Hydrocarbon Extraction Related to the Water System
}

\author{
Ann-Hélène Faber, Mark Annevelink, Herman Kasper Gilissen, Paul Schot, \\ Marleen van Rijswick, Pim de Voogt, and Annemarie van Wezel
}

Electronic supplementary material The online version of this article (https://doi.org/10.1007/ 398_2017_10) contains supplementary material, which is available to authorized users.

Ann-Hélène Faber $(\bowtie)$

Copernicus Institute of Sustainable Development, Faculty of Geosciences, Utrecht University, Utrecht, The Netherlands

KWR Watercycle Research Institute, Nieuwegein, The Netherlands

Institute for Biodiversity and Ecosystem Dynamics, University of Amsterdam, Amsterdam, The Netherlands

e-mail: a.faber1@uu.nl

M. Annevelink

KWR Watercycle Research Institute, Nieuwegein, The Netherlands

Department of Environmental Science, Radboud University Nijmegen, Nijmegen,

The Netherlands

e-mail: Mark.annevelink@kwrwater.nl

H.K. Gilissen · M. van Rijswick

Utrecht Centre for Water, Oceans and Sustainability Law, Faculty of Law, Economics and Governance, Utrecht University, Utrecht, The Netherlands

e-mail: h.k.gilissen@uu.nl; h.vanrijswick@uu.nl

P. Schot

Copernicus Institute of Sustainable Development, Faculty of Geosciences, Utrecht University, Utrecht, The Netherlands

e-mail: P.P.Schot@uu.nl

P. de Voogt

KWR Watercycle Research Institute, Nieuwegein, The Netherlands

Institute for Biodiversity and Ecosystem Dynamics, University of Amsterdam, Amsterdam, The Netherlands

e-mail: W.P.deVoogt@uva.nl
A. van Wezel
Copernicus Institute of Sustainable Development, Faculty of Geosciences, Utrecht University, Utrecht, The Netherlands
KWR Watercycle Research Institute, Nieuwegein, The Netherlands e-mail: Annemarie.van.Wezel@kwrwater.nl 


\section{Contents}

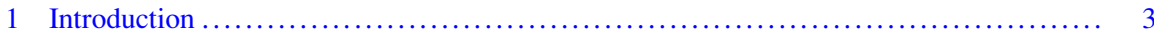

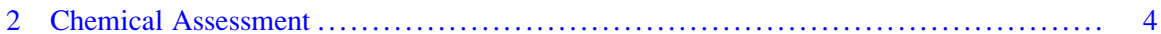

2.1 Chemicals Involved and Analytical Methods $\ldots \ldots \ldots \ldots \ldots \ldots \ldots \ldots \ldots \ldots \ldots \ldots \ldots$

2.2 Concentrations and Loads in UO\&G-Related Waters $\ldots \ldots \ldots \ldots \ldots \ldots \ldots \ldots \ldots \ldots \ldots$

2.3 Monitoring and Recommendations ................................... 12

3 Assessment of Hazardous Properties of the Chemicals ............................ 13

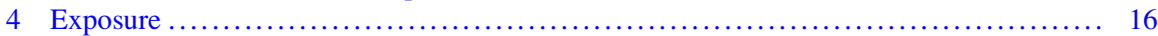

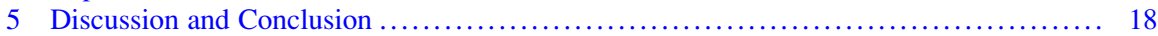

5.1 Reducing Risk by Adequate Wastewater Management and Technological

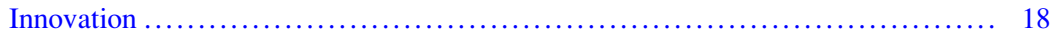

5.2 Identified Knowledge Gaps and Uncertainties ............................ 19

5.3 Implications for Risk Assessment and Legislation $\ldots \ldots \ldots \ldots \ldots \ldots \ldots \ldots \ldots \ldots \ldots .22$

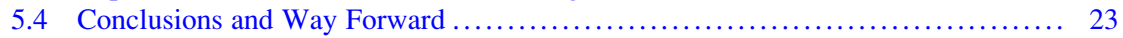

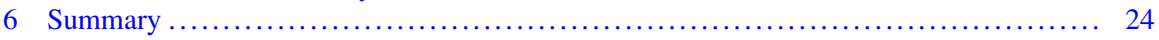

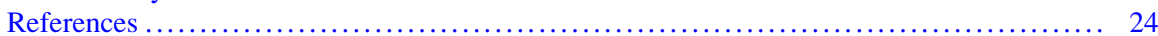

\section{Abbreviations}

\begin{tabular}{ll} 
AU & Australia \\
BMDL & Benchmark dose \\
CA & Concentration addition \\
DE & Germany \\
DWD & Drinking Water Directive \\
EC50 & Half maximal effective concentration \\
EU & European Union \\
GA & Glutaraldehyde \\
GWD & Groundwater Directive \\
IARC & International Agency for Research on Cancer \\
IEA & International Energy Agency \\
Koc & Soil organic carbon-water partition coefficient \\
LC-HRMS & Liquid chromatography high resolution mass spectrometry \\
Log Kow & $n$-octanol-water partition coefficient \\
MS & Mass Spectrometry \\
NOAEL & No adverse effect level \\
PBT & Persistent, bioaccumulative and toxic \\
PEC & Predicted environmental concentration \\
PNEC & Predicted no effect concentration \\
RfD & Reference dose \\
RQ & Risk quotient \\
TDS & Total dissolved solids \\
TDI & Tolerable daily intake \\
TTC & Threshold of toxicological concern \\
UK & United Kingdom \\
UO\&G & Unconventional oil and gas \\
USA & United States of America \\
WFD & Water Framework Directive \\
& \\
\hline &
\end{tabular}




\section{Introduction}

Unconventional oil and gas (UO\&G) resources represent large volumes of hydrocarbons trapped inside relatively impermeable rock layers, making them more difficult to access than conventional resources (Elliott et al. 2017; Werner et al. 2015). These energy sources include oil and gas from shale formations, limestone, sandstone, and coal deposits. In order to reach these formations, wells need to be drilled several kilometers deep followed by additional horizontal drilling in order to cover a larger area (Jackson et al. 2013a). Large amounts of water ( 90\%) mixed with proppants ( 9\%) such as sand and chemical additives ( 1\%) (Vidic et al. 2013) are injected into the formations. For well injection in shale, some 8-19 million $\mathrm{L}$ of fracturing fluid is needed per well to perform one hydraulic fracture resulting in high loads of chemicals (King 2012). While hydraulic fracturing was already developed in the 1940s (Montgomery and Smith 2010), technological advancements in directional drilling and reservoir stimulation have made the extraction of unconventional energy sources economically viable since the past few decades (Jackson et al. 2013a). Hydraulic fracturing might help to secure energy needs and is sometimes considered as a step in the transition from coal to renewable energy production (Howarth et al. 2011). However, the extraction of unconventional hydrocarbons might also delay the development of renewable and sustainable energy policies and technologies, by competing for investments and deviating public and political attention (Howarth et al. 2011).

There is an increasing public and scientific concern about air, soil, and water contamination, due to the possible adverse health and environmental effects (Gordalla et al. 2013; Grant et al. 2015; Elliott et al. 2017). This paper focuses on the water system, where contamination might result both from chemical additives used in drilling and fracturing fluids and from components naturally present in the subsoil that are brought to the surface via drill cuttings, flowback, and produced waters (Vidic et al. 2013). These substances include heavy metals, radionuclides, brine, and hydrocarbons. The majority of studies on water contamination related to UO\&G were carried out in the USA, i.e., Pennsylvania, Colorado, and Texas. Contamination after UO\&G operations is reported in drinking water for manganese (Alawattegama et al. 2015), stray gas (Osborn et al. 2011), arsenic, selenium, strontium, and total dissolved solids (Fontenot et al. 2013; USEPA 2016). In groundwater samples after UO\&G-related surface spills, benzene, toluene, ethylbenzene, and xylene exceeded drinking water guidelines (Gross et al. 2013), and brine contamination was reported (Preston and Chesley-Preston 2015). Water contamination can occur during gas extraction activities through surface and underground spills or leaks (Vidic et al. 2013). Wastewater disposal is a concern for water quality. In the USA, wastewater treatment plants are often used; however, they are not all well-equipped to efficiently treat the unconventional wastewaters. 
This might, after disposal of the treated effluents, lead to surface water and shallow groundwater contamination (Ferrar et al. 2013; Butkovskyi et al. 2017).

Chemical risk assessment is used to allow safe use of chemicals in an array of sectors and is typically done per single compound and type of use, combining information on hazardous properties with expected exposures (Van Wezel et al. 2017). Environmental exposure scenarios are typically limited to surface water and relatively shallow groundwater. UO\&G operations however have specific characteristics that might require adaptations of chemical risk assessment to properly assess the risks associated with these activities. The large number of chemicals involved might require further prioritization of these chemicals, e.g., with respect to risks for drinking water (Sjerps et al. 2016; Schriks et al. 2010a). Environmental fate processes including transformation might deviate from aboveground ones due to higher pressures and temperatures in the deep soil (Hoelzer et al. 2016), impacting chemical risk assessment.

Here, we identify and describe uncertainties and knowledge gaps of chemical risk assessment related to unconventional drillings, assess the available exposure models in relation to $\mathrm{UO} \& \mathrm{G}$, and propose adaptations where necessary and possible including attention to monitoring practices. We discuss how chemical risk assessment in the context of UO\&G differs from conventional chemical risk assessment and the implications for existing legislation concerning authorization of chemicals, unconventional drillings, and water quality.

\section{Chemical Assessment}

\subsection{Chemicals Involved and Analytical Methods}

The additives used in fracturing and drilling fluid include biocides, scale and corrosion inhibitors, oxygen scavengers, cleaners, gelling agents, friction reducers, iron controls, surfactants, cross-linkers, breakers, conditioners, and clay stabilizers. The number and volume of chemicals needed depend on the local subsurface conditions and chemical properties of the water used (Vidic et al. 2013). FracFocus Chemical Disclosure Registry (US Fracfocus 2016; Soeder et al. 2014) is a US database that contains over 1,100 different chemicals documented to be used during hydraulic fracturing so far, including a description of their purpose. Although registration is mandatory in several US states in order to get licenses, due to property rights and trade policies in many cases, exceptions are possible (Centner and O'Connell 2014; Maule et al. 2013). The quality of the entries in this database can be improved with regard to incorrectly reported CAS numbers, the use of different names for the same chemical, spelling mistakes, etc. In Europe, the International Association of Oil and Gas Producers introduced a registry still on a voluntary basis which for the moment only contains chemicals used in Polish unconventional drilling sites (NGS 2016). Poland as the most active European state in shale gas exploration and production provides a separate chemical registry 
(OPPPW 2016). Local operators in other European countries also provide registries (NAM 2016; Cuadrilla 2016; ExxonMobile 2016).

Subsurface contaminants, i.e., heavy metals, radionuclides, salts, and hydrocarbons, are mobilized during drilling and hydraulic fracturing activities (Jackson et al. 2013b). Both drilling and hydraulic fracturing activities mobilize contaminants from the formation, and drilling mobilizes more diverse contaminants from overlying layers. There are currently no databases for subsurface contaminants, but many of the contaminants can be found in literature (Online Resource 1 - ESM 4; Abualfaraj et al. 2014; Alawattegama et al. 2015; Dahm et al. 2011; Ferrar et al. 2013; Fontenot et al. 2013; Grant et al. 2015; Gregory et al. 2011; Gross et al. 2013; Hayes 2009; Hayes and Severin 2012; Heilweil et al. 2015; Hildenbrand et al. 2015; Hladik et al. 2014; Lester et al. 2015; Maguire-Boyle and Barron 2014; Orem et al. 2014; Olsson et al. 2013; Osborn et al. 2011; Preston and Chesley-Preston 2015; Tang et al. 2014; Thacker et al. 2015; Warner et al. 2013a, b; Ziemkiewicz et al. 2014).

In view of the large number of chemicals that can be involved in hydraulic fracturing activities, there is a need for advanced analytical techniques to identify chemicals present in fracturing fluid, flowback and produced waters, shallow and deeper groundwaters, and treated wastewaters. For inorganic compounds, inductive coupled plasma mass spectrometry is generally used (Chapman et al. 2012; Strong et al. 2013; Ferrer and Thurman 2015b), although atomic absorption has also been utilized (Barbot et al. 2013; Ferrer and Thurman 2015b). Thermal ionization mass spectrometry may be used for radionuclide analysis (Chapman et al. 2012; Warner et al. 2013a; Ferrer and Thurman 2015b). Gas chromatography mass spectrometry (GCMS) may be used for organic volatile compounds, such as methane. For relatively polar organic compounds, high-resolution mass spectrometry (HRMS) may be used to perform both target and nontarget screening analysis (Hogenboom et al. 2009; Krauss et al. 2010; Ferrer and Thurman 2015a, b; Leendert et al. 2015; Schymanski et al. 2014a, b, 2015). Chemical MS analysis can provide quantification of single chemicals if standards are used and otherwise semi-quantification based on internal standard equivalents (e.g., Sjerps et al. 2016). MS analysis is only able to detect ionizable compounds, i.e., compounds that have at least one heteroatom (e.g., N, S, O, and P). Further details on sample preparation have been described by Ferrer and Thurman (2015b).

Nontarget screening differs from target screening in that it aims to detect all the substances present in a given sample, limited only by the analytical detection method (Müller et al. 2011). A list of 1,386 chemicals that might be expected in the UO\&G water samples has been prepared using the aforementioned databases and literature (Online Resource 1 - ESM 1). The UO\&G suspect list provides the compound names, the corresponding chemical formulas, CAS numbers, molecular weights, and their type of use (i.e., biocide, scale inhibitor, subsurface contaminant, etc.) where possible. Chemical formulas and molecular weights are based on Sjerps et al. (2016), PubChem, ChemSpider, and Toxnet. For the fracturing fluid additives, purposes and additive classes were indicated based on the US FracFocus database. The accurate masses in the UO\&G suspect list can be used to compare with accurate 
masses of chemicals found in hydraulic fracturing-related water samples using liquid chromatography (LC)-HRMS suspect screening after which the identification can be further confirmed (Bletsou et al. 2015; Hug et al. 2014; Schymanski et al. 2014b). For this purpose the list needs to be reduced to only include ionizable compounds that can be detected with LC-HRMS (Online Resource 1 - ESM 2; Sjerps et al. 2016). The list is made up of $21 \%$ subsurface contaminants and $79 \%$ fracturing fluid additives (Fig. 1). Most of the additives have multiple functions (27\%), followed by tracers (21\%) and corrosion inhibitors (8\%). The other purposes (base fluid, biocide, breaker, clay control, cross-linker, friction reducer, gelling agent, iron control, proppant, scale inhibitor, surfactant) all fall below 5\%. The detailed composition of the 5\% other can be found in Online Resource 1-ESM 5a. Some compounds were registered as "additional ingredients," without further detail on their specific function. Only $44 \%$ and $52 \%$ of the compounds of the complete and the reduced lists, respectively, are regulated in the EU (Table 1; ECHA 2017).

\section{Composition of hydraulic fracturing related suspect list}

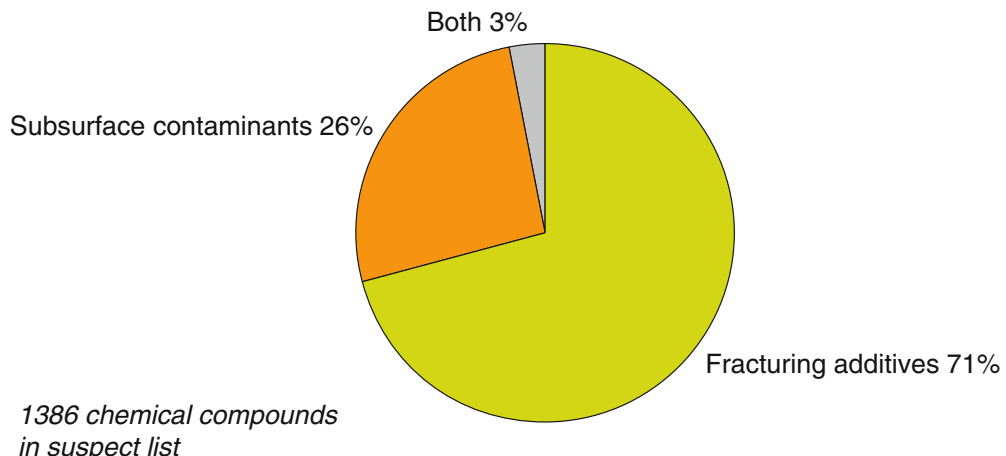

\section{Overview of fracturing fluid additive purposes}

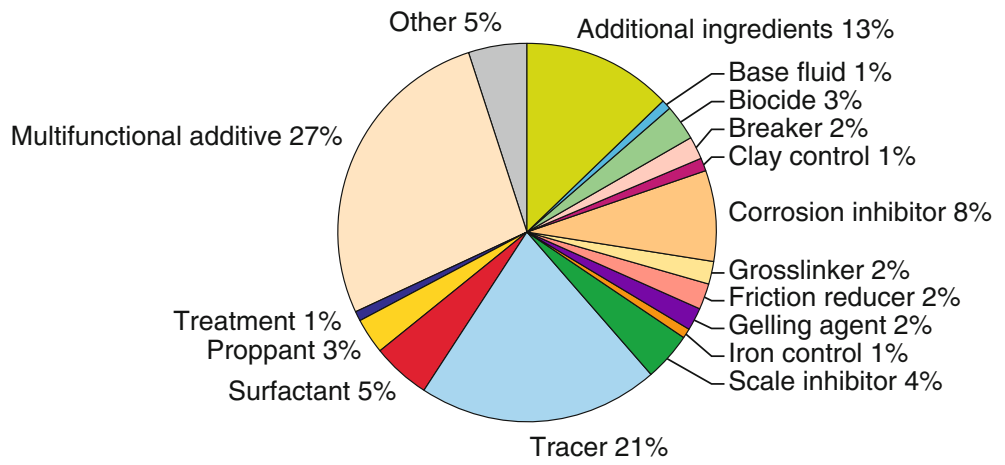

Fig. 1 Composition of UO\&G suspect list, including an overview of the fracturing fluid additive purposes (Online Resource 1 - ESM 5b and 6a) 
Table 1 Suspect list compounds regulated in Europe (Online Resource 1 - ESMs 1 and 2)

\begin{tabular}{l|l|l|l|l}
\hline & $\begin{array}{l}\text { Complete } \\
\text { list }\end{array}$ & $\begin{array}{l}\text { EU } \\
\text { regulated }\end{array}$ & $\begin{array}{l}\text { LC-HRMS analyzable } \\
\text { List }\end{array}$ & $\begin{array}{l}\text { EU } \\
\text { regulated }\end{array}$ \\
\hline Total suspects & 1,386 & $606(44 \%)$ & 462 & $242(52 \%)$ \\
\hline Fracturing additives & 1,043 & $473(45 \%)$ & 304 & $184(61 \%)$ \\
\hline $\begin{array}{l}\text { Subsurface } \\
\text { contaminants }\end{array}$ & 325 & $133(41 \%)$ & 158 & $58(37 \%)$ \\
\hline
\end{tabular}

This means that if unconventional hydrocarbons were to be extracted on a large scale in Europe, there would either be a limited number of compounds to choose from for the composition of the fracturing fluid or more work needs to be done in regulating these compounds.

Chemical mixture effects cannot be covered by chemical analysis alone (Escher and Leusch 2012). Effect-directed analysis, using in vitro bioassays, complements the chemical MS analysis and provides insight into all bioactive chemicals (Kolkman et al. 2013). In vitro analysis provides a good base in toxicological endpoints for health risks (Arini et al. 2016; Escher et al. 2013; Leusch et al. 2017; Murk et al. 2002; Nelson et al. 2007; Poulsen et al. 2011; Brand et al. 2013; Schriks et al. 2010b). More specifically, UO\&G-related chemicals have been associated with adverse developmental and reproductive effects (Webb et al. 2014) and endocrine-disrupting effects (Kassotis et al. 2013, 2015, 2016a, b), so a hormonal-based and/or a reproductive-/developmental-based assessment of water mixtures related to UO\&G operations could be of importance for detecting contamination due to $U O \& G$ activities.

\subsection{Concentrations and Loads in UO\&G-Related Waters}

The reported concentrations of chemicals used and mobilized during UO\&G operations in related water for shale gas were recently reviewed by Annevelink et al. (2016). Here we actualize and extend this information for other types of unconventional hydraulic fracturing (Table 2). Figure 2a, b presents a selection of compounds measured in all three matrices, i.e., surface water or groundwater, flowback or produced water, and wastewater. An overview of reported concentrations for all compounds can be found in Online Resource 2 (ESM1). Of all of the compounds analyzed in literature, most were analyzed in flowback and produced waters $(72 \%)$, followed by fracturing fluid (59\%) and surface water and groundwater (59\%). In addition, most compounds were measured in relation to shale gas operations (84\%), followed by coal-bed methane $(53 \%)$, and only very few were measured for tight gas and conventional gas (11\%; Online Resource 2 - ESM 3).

Baseline data is often not ensured, which complicates conclusions on the significance of UO\&G as source of contamination (Lange et al. 2013). Generally, the highest concentrations can be found in flowback and produced waters, whereas 
Table 2 Overview of matrices, formations, locations, and compound types analyzed in literature

\begin{tabular}{|c|c|c|c|c|}
\hline Water type & UO\&G type & Location & $\begin{array}{l}\text { Compounds } \\
\text { measured }\end{array}$ & Reference \\
\hline \multirow[t]{3}{*}{$\begin{array}{l}\text { Fracturing } \\
\text { fluid }\end{array}$} & Shale gas & Pennsylvania (US) & $\begin{array}{l}\text { Inorganics } \\
\text { and organics }\end{array}$ & $\begin{array}{l}\text { Ziemkiewicz } \\
\text { et al. (2014) }\end{array}$ \\
\hline & Shale gas & $\begin{array}{l}\text { Pennsylvania and West } \\
\text { Virginia - Marcellus (US) }\end{array}$ & $\begin{array}{l}\text { Inorganics } \\
\text { and organics }\end{array}$ & Hayes (2009) \\
\hline & Shale gas & $\begin{array}{l}\text { Barnett and Appalachian } \\
\text { shale (US) }\end{array}$ & $\begin{array}{l}\text { Inorganics } \\
\text { and organics }\end{array}$ & $\begin{array}{l}\text { Hayes and } \\
\text { Severin (2012) }\end{array}$ \\
\hline \multirow[t]{16}{*}{$\begin{array}{l}\text { Flowbackl } \\
\text { produced }\end{array}$} & Shale gas & $\begin{array}{l}\text { Pennsylvania, New York, } \\
\text { West Virginia (US) }\end{array}$ & $\begin{array}{l}\text { Inorganics } \\
\text { and organics }\end{array}$ & $\begin{array}{l}\text { Abualfaraj et al. } \\
\text { (2014) }\end{array}$ \\
\hline & Shale gas & $\begin{array}{l}\text { Pennsylvania and West } \\
\text { Virginia - Marcellus (US) }\end{array}$ & $\begin{array}{l}\text { Inorganics } \\
\text { and organics }\end{array}$ & Hayes (2009) \\
\hline & Shale gas & $\begin{array}{l}\text { Barnett and Appalachian } \\
\text { shale (US) }\end{array}$ & $\begin{array}{l}\text { Inorganics } \\
\text { and organics }\end{array}$ & $\begin{array}{l}\text { Hayes and } \\
\text { Severin (2012) }\end{array}$ \\
\hline & Shale gas & Colorado (US) & $\begin{array}{l}\text { Inorganics } \\
\text { and organics }\end{array}$ & $\begin{array}{l}\text { Lester et al. } \\
\text { (2015) }\end{array}$ \\
\hline & Shale gas & $\begin{array}{l}\text { Pennsylvania, Texas, New } \\
\text { Mexico (US) }\end{array}$ & $\begin{array}{l}\text { Inorganics } \\
\text { and organics }\end{array}$ & $\begin{array}{l}\text { Maguire-Boyle } \\
\text { and Barron } \\
(2014)\end{array}$ \\
\hline & Shale gas & $\begin{array}{l}\text { Cappeln, Damme, } \\
\text { Buchhorst (DE) }\end{array}$ & Inorganics & $\begin{array}{l}\text { Olsson et al. } \\
(2013)\end{array}$ \\
\hline & Shale gas & $\begin{array}{l}\text { Pennsylvania, Indiana, } \\
\text { Kentucky (US) }\end{array}$ & Organics & $\begin{array}{l}\text { Orem et al. } \\
\text { (2014) }\end{array}$ \\
\hline & Shale gas & Pennsylvania (US) & Inorganics & $\begin{array}{l}\text { Warner et al. } \\
\text { (2013a) }\end{array}$ \\
\hline & Shale gas & US & $\begin{array}{l}\text { Inorganics } \\
\text { and organics }\end{array}$ & $\begin{array}{l}\text { Thacker et al. } \\
\text { (2015) }\end{array}$ \\
\hline & Shale gas & Marcellus gas wells (US) & $\begin{array}{l}\text { Inorganics } \\
\text { and organics }\end{array}$ & $\begin{array}{l}\text { Ziemkiewicz } \\
\text { et al. (2014) }\end{array}$ \\
\hline & Shale gas & $\begin{array}{l}\text { Marcellus shale (Western } \\
\text { Pennsylvania - US) }\end{array}$ & Inorganics & $\begin{array}{l}\text { Gregory et al. } \\
\text { (2011) }\end{array}$ \\
\hline & $\begin{array}{l}\text { Coal-bed } \\
\text { methane }\end{array}$ & $\begin{array}{l}\text { Illinois, Alabama, Wyo- } \\
\text { ming, Montana, North } \\
\text { Dakota (US) }\end{array}$ & Organics & $\begin{array}{l}\text { Orem et al. } \\
(2014)\end{array}$ \\
\hline & $\begin{array}{l}\text { Coal-bed } \\
\text { methane }\end{array}$ & $\begin{array}{l}\text { Colorado, Wyoming, New } \\
\text { Mexico (US) }\end{array}$ & $\begin{array}{l}\text { Inorganics } \\
\text { and organics }\end{array}$ & $\begin{array}{l}\text { Dahm et al. } \\
\text { (2011) }\end{array}$ \\
\hline & $\begin{array}{l}\text { Coal-bed } \\
\text { methane }\end{array}$ & US & Inorganics & $\begin{array}{l}\text { Thacker et al. } \\
(2015) \text {; Alley } \\
\text { et al. }(2011)\end{array}$ \\
\hline & Tight gas & US & Inorganics & $\begin{array}{l}\text { Thacker et al. } \\
\text { (2015); Alley } \\
\text { et al. (2011) }\end{array}$ \\
\hline & $\begin{array}{l}\text { Conventional } \\
\text { gas }\end{array}$ & US & Inorganics & $\begin{array}{l}\text { Thacker et al. } \\
\text { (2015); Alley } \\
\text { et al. (2011) }\end{array}$ \\
\hline
\end{tabular}


Table 2 (continued)

\begin{tabular}{|c|c|c|c|c|}
\hline Water type & UO\&G type & Location & $\begin{array}{l}\text { Compounds } \\
\text { measured }\end{array}$ & Reference \\
\hline \multirow{14}{*}{$\begin{array}{l}\text { Surface water } \\
\text { and } \\
\text { groundwater }\end{array}$} & Shale gas & Pennsylvania (US) & Inorganics & $\begin{array}{l}\text { Alawattegama } \\
\text { et al. (2015) }\end{array}$ \\
\hline & Shale gas & Texas (US) & $\begin{array}{l}\text { Inorganics } \\
\text { and organics }\end{array}$ & $\begin{array}{l}\text { Fontenot et al. } \\
\text { (2013) }\end{array}$ \\
\hline & Shale gas & Pennsylvania (US) & $\begin{array}{l}\text { Inorganics } \\
\text { and organics }\end{array}$ & $\begin{array}{l}\text { Ferrar et al. } \\
\text { (2013) }\end{array}$ \\
\hline & Shale gas & $\begin{array}{l}\text { Pennsylvania, New York } \\
\text { (US) }\end{array}$ & $\begin{array}{l}\text { Inorganics } \\
\text { and organics }\end{array}$ & $\begin{array}{l}\text { Osborn et al. } \\
\text { (2011) }\end{array}$ \\
\hline & Shale gas & $\begin{array}{l}\text { Montana, North Dakota } \\
\text { (US) }\end{array}$ & Inorganics & $\begin{array}{l}\text { Preston and } \\
\text { Chesley-Preston } \\
\text { (2015) }\end{array}$ \\
\hline & Shale gas & Pennsylvania (US) & Inorganics & $\begin{array}{l}\text { Warner et al. } \\
\text { (2013a) }\end{array}$ \\
\hline & Shale gas & Arkansas (US) & Inorganics & $\begin{array}{l}\text { Warner et al. } \\
(2013 b)\end{array}$ \\
\hline & Shale gas & Marcellus gas wells (US) & $\begin{array}{l}\text { Inorganics } \\
\text { and organics }\end{array}$ & $\begin{array}{l}\text { Ziemkiewicz } \\
\text { et al. (2014) }\end{array}$ \\
\hline & Shale gas & Pennsylvania (US) & Organics & $\begin{array}{l}\text { Heilweil et al. } \\
\text { (2015) }\end{array}$ \\
\hline & Shale gas & Pennsylvania (US) & Inorganics & $\begin{array}{l}\text { Grant et al. } \\
\text { (2015) }\end{array}$ \\
\hline & Shale gas & $\begin{array}{l}\text { Marcellus shale (Colo- } \\
\text { rado, US) }\end{array}$ & Organics & $\begin{array}{l}\text { Gross et al. } \\
\text { (2013) }\end{array}$ \\
\hline & Shale gas & Barnett shale (Texas, US) & $\begin{array}{l}\text { Inorganics } \\
\text { and organics }\end{array}$ & $\begin{array}{l}\text { Hildenbrand } \\
\text { et al. (2015) }\end{array}$ \\
\hline & $\begin{array}{l}\text { (Un)conven- } \\
\text { tional gas }\end{array}$ & $\begin{array}{l}\text { Pennsylvania, Colorado, } \\
\text { Maryland, Virginia (US) }\end{array}$ & Organics & $\begin{array}{l}\text { Hladik et al. } \\
\text { (2014) }\end{array}$ \\
\hline & $\begin{array}{l}\text { Coal-bed } \\
\text { methane }\end{array}$ & Queensland (AU) & Inorganics & Tang et al. (2014) \\
\hline
\end{tabular}

US United States, $D E$ Germany, $A U$ Australia

the lowest concentrations are found in surface/shallow aquifers (Fig. 2a, b, Online Resource 2 - ESM 2a). Most studies focus on chemicals present in wastewater, followed by surface and shallow aquifers. Only few studies (Ziemkiewicz et al. 2014; Hayes 2009; Hayes and Severin 2012) measured compounds in fracturing fluid. Although contamination in one matrix can influence a subsequent matrix, no study analyzed the whole cycle from fracturing fluid, flowback and produced water, and surface water and groundwater related to UO\&G operations.

The majority of available studies focus on the US UO\&G operations: only two studies are available from Australia and Germany (Table 2). Most studies reported concentrations of chemicals in water from shale gas activities (Table 2); only few studies (Dahm et al. 2011; Orem et al. 2014; Thacker et al. 2015; Alley et al. 2011) relate to coal-bed methane, tight sand gas, or conventional gas-related activities. 


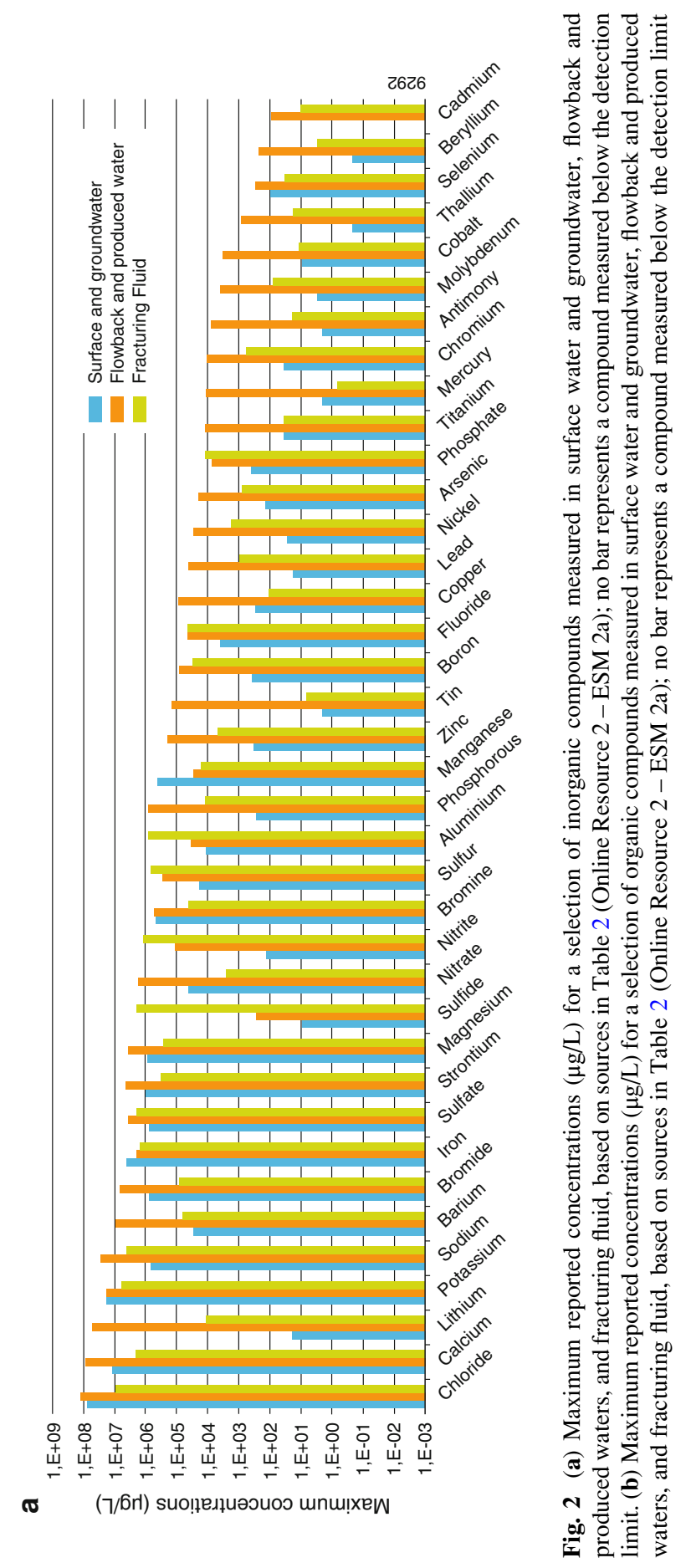




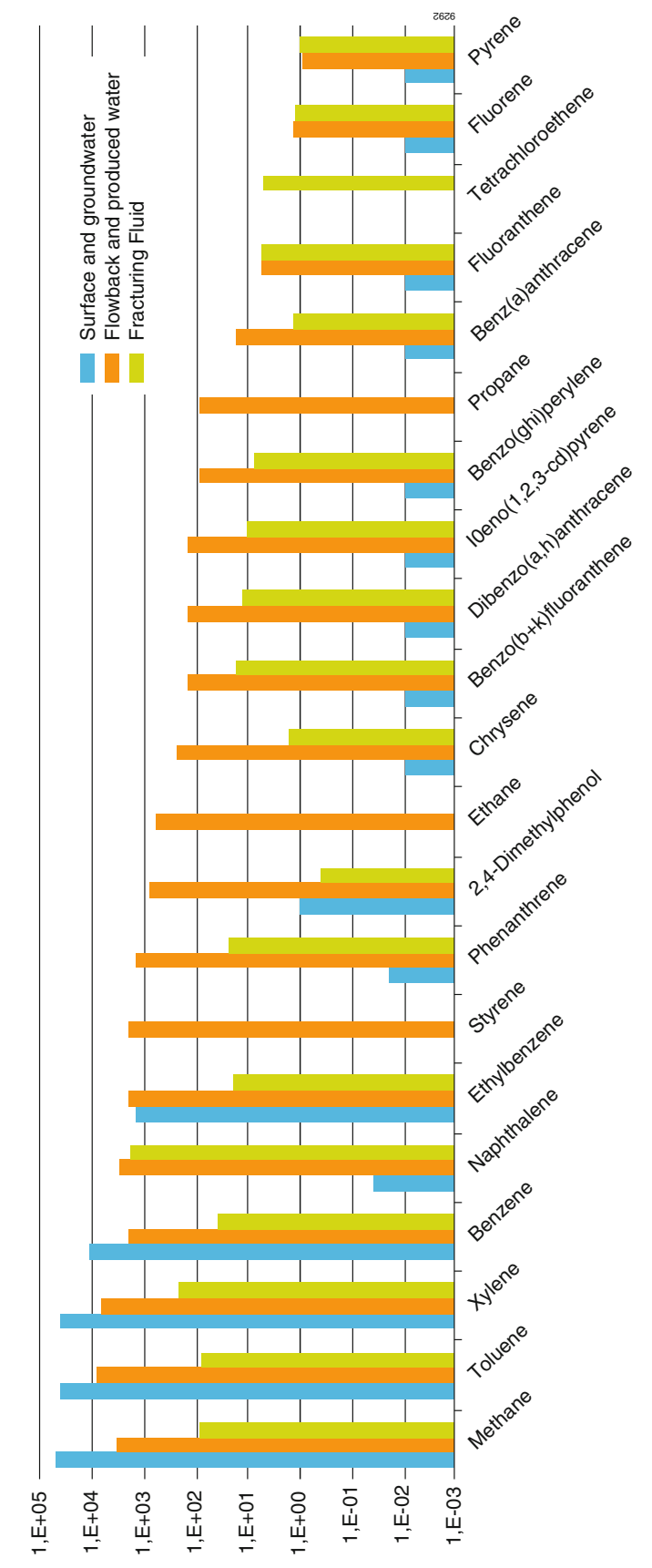

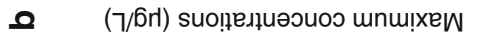


This attention toward shale gas is explained by its high production; in IEA member countries excluding China and Albania due to missing data, 58\% of the UO\&G relates to shale, while $34 \%$ and $8 \%$ relate to tight sand gas and coal-bed methane, respectively (IEA 2017).

Generally in the found literature, target screening was used, probably missing contaminants of concern. The majority of the chemicals from the UO\&G suspect list are not measured in the available literature, for only $4 \%$ information is available (Online Resource 1 - ESM 6b). So, because of this scarce data availability, it is still difficult to address the risks of UO\&G for water systems (Jackson et al. 2013b).

\subsection{Monitoring and Recommendations}

Routine surface water and groundwater monitoring practices are currently not designed to consider specific risks associated with UO\&G operations. The Water Framework Directive (WFD; 2000/60/EC), including the Groundwater Directive (GWD; 2006/118/EC) and the Drinking Water Directive (DWD; 98/83/EC), outlines requirements for monitoring of surface water and groundwater in Europe, related to the physical, chemical, and biological water characteristics. The intensity of monitoring effort, however, varies hugely among water bodies (Malaj et al. 2014). Generally, deep ( $>100 \mathrm{~m})$ groundwater is not monitored, while anthropogenic effects on groundwater can remain for decades (Sophocleous 2002). General water quality monitoring is not specified to chemicals related to UO\&G practices or the transformation products that may be formed during the hydraulic fracturing process (Hoelzer et al. 2016). Furthermore, Harris et al. (2016) highlight the difficulty in detecting spill events: the distance travelled by a contaminant strongly affects its concentration in surface water, potentially leading to very subtle concentration changes depending on the monitoring location. Burton et al. (2016) found that beryllium is a good indicator for evaluating UO\&G-related impacts on regional groundwater quality, in the Barnett Shale formation. Such indicators could also be determined for other important UO\&G formations.

We recommend regular long-term monitoring of the whole UO\&G-related water cycle including baseline data in the surroundings of UO\&G operations, focusing on the specific persistent and mobile chemicals used, their transformation products, and the chemicals originating from the subsoil (cf. Vidic et al. 2013). Baseline data is needed in order to monitor changes resulting from the UO\&G activities. Regular long-term monitoring ensures the timely detection of leaks after the well has been abandoned so that remediation efforts can quickly be put in place (Patterson et al. 2017; Maloney et al. 2017). Such monitoring programs could include effectdirected analysis (Brack et al. 2017; Venkatesan and Halden 2015). A significant increase in monitoring data related to a variety of geological and hydrological situations will improve our understanding of groundwater contamination related to UO\&G operations (Soeder 2015). Indeed, the Commission Recommendation 
(2014/70/EU) on hydraulic fracturing does provide UO\&G-tailored provisions about, inter alia, risk assessments, monitoring, and baseline studies, but due to its non-binding nature, its effectiveness yet remains uncertain. Therefore, in order to better implement the above recommendations and to increase compliance potential and uniformity in practices, it should be taken into consideration to include them into the general framework of EU water legislation, preferably building upon and further specifying existing soft law documents, such as Recommendation 2014/70/EU.

\section{Assessment of Hazardous Properties of the Chemicals}

After chemical analysis, not only a list of chemicals present in UO\&G-related waters is obtained but also their concentrations. These include chemicals with high and low toxicological concern for humans and the environment. In the EU, industrial chemicals and biocides used in the fracturing fluids are registered and authorized via the REACH regulation (EC 1907/2006) and the Biocidal Products Regulation (EU 528/2012). REACH defines chemicals of concern as persistent, bioaccumulative, and toxic (PBT; EC 1907/2006 - Annex XIII REACH). For water contamination, relatively hydrophilic compounds are more problematic compared to bioaccumulative chemicals (Reemtsma et al. 2016, Westerhoff et al. 2005, Sjerps et al. 2016). Chemicals that have carcinogenic, mutagenic, and toxic reproductive properties are defined in REACH as chemicals of concern (CMR; EC 1907/2006Annex VI of CLP regulation). Water quality requirements are presented in the European WFD, including the GWD, and in the DWD. However, as valid for chemicals in general, most of them used in drilling and fracturing fluid are not regulated by drinking water or water quality regulations other than in a generic sense. For non-regulated chemicals provisional water quality limits based on substance specific toxicity data can be used to estimate safe exposure levels (Schriks et al. 2010a). In absence of the latter, the more conservative and precautionary concept of thresholds of toxicological concern (TTC) can be used (Mons et al. 2013; Kroes et al. 2005) as based on toxicological data from a representative set of compounds. For drinking water, this conservative value is set at 0.1 and $0.01 \mu \mathrm{g} / \mathrm{L}$ for organic compounds and for genotoxicant and endocrine active chemicals, respectively (Mons et al. 2013). Provisional water quality limits, based on chemical specific toxicity data, can be orders of magnitudes less stringent (Schriks et al. 2010a).

The toxicological information available regarding chemicals related to UO\&G operations is generally limited. Elliott et al. (2017) noted that more than $80 \%$ of the compounds of a list of UO\&G-related water contaminants and air pollutants were not evaluated as to their carcinogenicity by IARC. In the USA, $87 \%$ of all chemicals used in fracturing fluids are not assessed for chronic toxicological effects (Yost et al. 2016). Furthermore, Shonkoff et al. (2014) identified the need for more epidemiological studies to assess UO\&G water pollution in combination with adverse health effects among people living close to UO\&G operations. This is 
corroborated by Stringfellow et al. (2014) who collected physicochemical and toxicological data for 81 fracturing fluid additives and did not find toxicological information for 30 of these chemicals.

Human and ecotoxicity are evaluated based on different endpoints, including acute toxicity tests, but also chronic endpoints such as carcinogenicity, mutagenicity or development, and reproduction. The available toxicological information varies strongly among chemicals, e.g., regarding the number of species tested, the endpoints studied, the duration, and pathways of exposure. Not all toxicological data available in the dossiers for registration and authorization is available in open literature and databases. If hardly any toxicological information is available, risks can be estimated using QSAR or read-across approaches (Gramatica 2007; Lee and Von Gunten 2012; Kühne et al. 2013; Scholz et al. 2013). There are several databases available for toxicological information on chemicals, e.g., Toxnet, the Hazardous Substances Data Bank (HSDB), the International Toxicity Estimates for Risk (ITER), the International Programme on Chemical Safety INCHEM Database, and OECD's eChemPortal. These databases include information from US National Toxicology Program (NTP). The International Agency for Research on Cancer (IARC) classifies carcinogenic compounds. Remaining information can be found in peer-reviewed scientific literature, using, e.g., scopus or google scholar search engines, by using keywords "toxicity, reference dose (RfD), acceptable daily intake (ADI), tolerable daily intake (TDI), no adverse effect level (NOAEL), and benchmark dose lower confidence limit for a 10\% response (BMDL10)" combined with the chemical name or CAS number. The OECD QSAR toolbox can be used to fill in the gaps in (eco)toxicity data.

Table 3 provides an overview of (eco)toxicological data for a selection of five chemicals with high concentrations in surface water and groundwater, fracturing and produced water, and fracturing fluid. Carcinogenic data, genotoxic data, developmental/reproductive toxicity, NOAEL, TDI, and reference doses were available for all chemicals. Benzene has the lowest reference dose, followed by naphthalene, toluene, ethylbenzene, and lastly xylene. The lowest EC50 value was taken for every chemical in order to evaluate the worst-case scenario. BMDL data was only available for a few chemicals. These results show that for these very well-known chemicals, toxicological data is generally available. EPA's Ecotox database is a good source for toxicological data in terms of completeness. However, for some toxicological data, the information is scattered over different sources.

Although concentrations of chemicals in UO\&G-related wastewater generally exceed TTC values (Fig. 2), this only becomes problematic if these untreated waters come into contact with freshwater reservoirs. Almost half of the organic compounds analyzed in surface water and groundwater exceed TTC values, indicating that further detailed risk assessment is needed and risks related to the extraction of UO\&G cannot be waived beforehand. Assessing the toxicological effect of mixtures is important for unconventional drilling activities because of the large variety of chemical additives or subsurface contaminants involved (Riedl et al. 2013). It is generally accepted that the concept of concentration addition (CA) can be used as a precautious first tier to assess mixture toxicity (Backhaus and Faust 2012; SCHER 


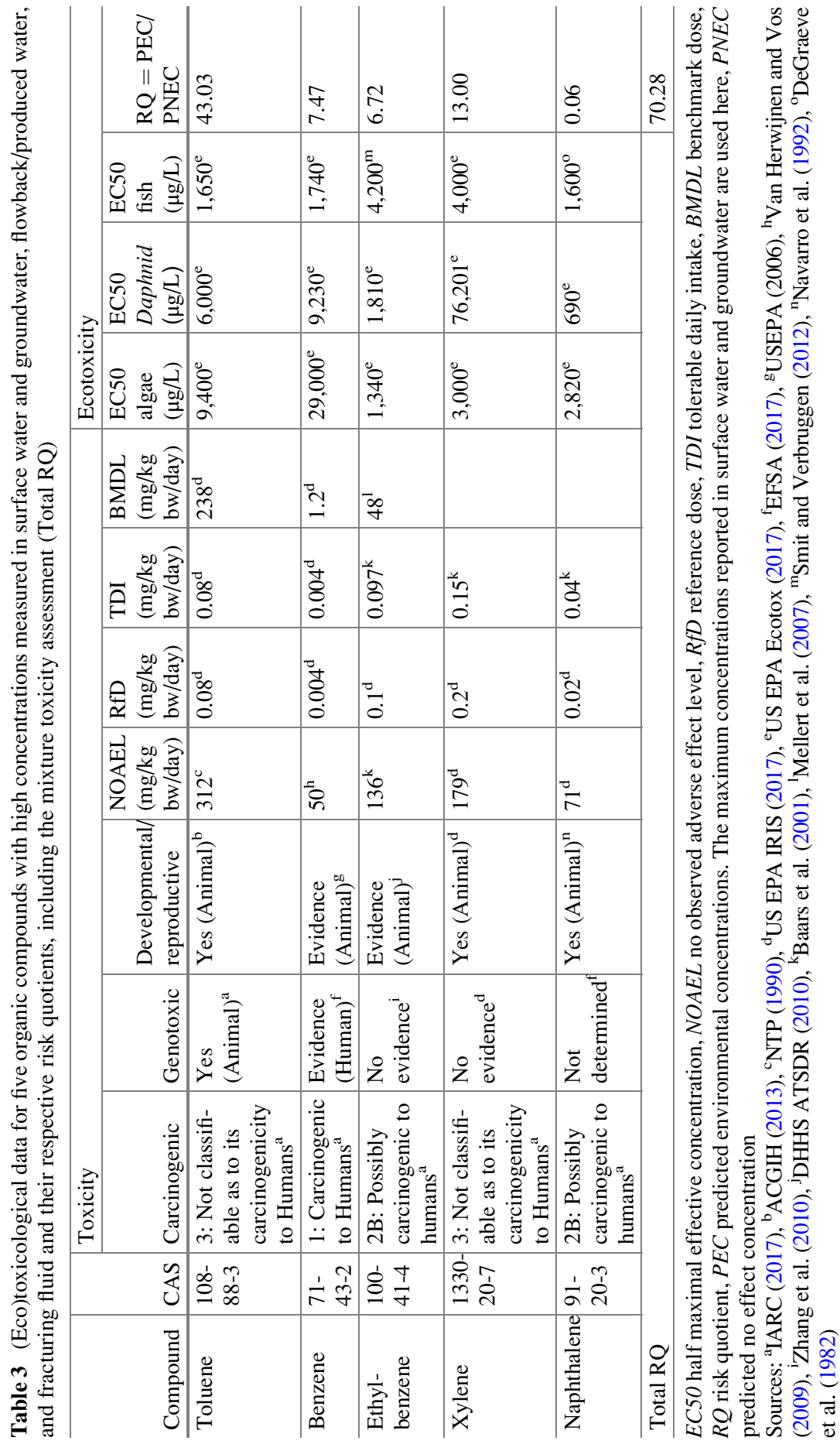


SCENIHR SCCS 2012). A mixture made up of the organic compounds among the five highest reported concentrations in surface water/groundwater, flowback/production water, and fracturing fluid represents a high risk quotient (RQ) of 70.28 (Table 3). Except for naphthalene, all of the chemicals have RQs higher than 1 , indicating a risk, toluene showing the highest RQ. This calculation is based on a realistic worst-case scenario, with maximum reported concentrations in surface water and groundwater, as well as minimum reported EC50 used. An assessment factor of 1,000 was applied. A comparable PEC-/PNEC-based risk assessment has also been conducted by Butkovskyi et al. (2017) for a selection of commonly used organic chemicals in UO\&G-related operations. They identified a number of potentially harmful compounds from the shale formation (polycyclic aromatic hydrocarbons, phthalates), from the fracturing fluids (quaternary ammonium biocides, 2-butoxyethanol), and as a result of downhole transformation (carbon disulfide, halogen).

\section{Exposure}

Chemicals having hazardous properties will only lead to risks if humans or ecosystems are exposed. To estimate exposure, both the emission rates and the chemical fate processes are important. However, no specific exposure scenarios toward groundwater aquifers exist for UO\&G-related activities. Human errors in various stages of the life cycle of UO\&G production play an important role in these exposure scenarios. Surface water and groundwater contamination might occur at the surface via accidental spills or in the subsoil via leaks (Gordalla et al. 2013) due to structure integrity problems or human errors. Surface spills can affect surface waters and shallow aquifers via infiltration or direct leaching. Underground leaks can affect aquifers via migration through artificial and/or natural faults and fractures. Spills and/or leaks related to human error occur mainly due to insufficient cementing, leaking connectivity, and blowouts (Table 4). Accidental surface spills do not seem to impact groundwater systems but do however impact surface waters (Harkness et al. 2017). Emission of the UO\&G-related chemicals highly depends on failure probabilities. These can be estimated for surface or near-surface spills and leaks by considering publicly available data on spill occurrences and released volumes from the USA. Failures and consequently leak volumes occurring deep underground could be underreported in these databases due to the lack of monitoring at these depths, even though monitoring of pressure decreases might be ensured. Due to the scarcity of UO\&G-related operations in the EU, there is little information available on spill frequencies and volumes for the European situation, meaning that related studies must rely on US databases. Identification of failures related to human error and their frequencies and spill/leak volumes from 2010 to 2015 are summarized in Table 4. The data is based on publicly available US governmental databases (NRC 2014; COGC 2014; OCD 2014; PADEP 2014; RRC 2014). The failure probability ranges were determined by relating the number of incidents to 
Table 4 Spill/leak probabilities and spill volume estimates based on US publicly available databases (2010-2015): National Response Center (NRC), Colorado Oil and Gas Commission (COGC), Oil Conservation Division (OCD), Pennsylvania Department of Environmental Protections (PADEP), and Railroad Commission Texas (RRC)

\begin{tabular}{l|l|l|l}
\hline $\begin{array}{l}\text { Contamination } \\
\text { pathway }\end{array}$ & Fluid released & $\begin{array}{l}\text { Frequency }(\% / w e l l / \\
\text { year})\end{array}$ & Average spill volume $\left(\mathrm{m}^{3}\right)$ \\
\hline \multirow{2}{*}{ Surface spill } & Drilling mud & $0.005-2.8$ & $294 \pm 185.7$ \\
\cline { 2 - 4 } & Fracturing fluid & $0.02-0.1$ & $24 \pm 28$ \\
\cline { 2 - 4 } & Produced water & $0.02-4.4$ & $12 \pm 29.1$ \\
\cline { 2 - 4 } & Oil-based fluid & $0.05-2.8$ & $1 \pm 6$ \\
\hline \multirow{2}{*}{ Blowout } & Drilling mud & 0.004 & $185 \pm 256$ \\
\cline { 2 - 4 } & Produced water & $0.0002-0.01$ & $3,206 \pm 7,843$ \\
\cline { 2 - 4 } & Oil-based fluid & $0.002-0.01$ & $49 \pm 243$ \\
\hline \multirow{2}{*}{$\begin{array}{l}\text { Leaking connectivity } \\
\text { Corroding well }\end{array}$} & Drilling mud & 0.01 & $43 \pm 50$ \\
\cline { 2 - 4 } casing & Produced water & 0.2 & $12 \pm 26$ \\
\cline { 2 - 4 } & Oil-based fluid & 0.1 & $4 \pm 20$ \\
\hline Insufficient & Oil-based fluid & $0.05-0.7$ & $11 \pm 41$ \\
\cline { 2 - 4 } cementing & Drilling mud & $0.001-0.004$ & Not specified \\
\cline { 2 - 4 } & Produced water & $0.002-1$ & \\
\hline
\end{tabular}

the active wells in the relevant time frame and area for each database. The spill/leak volumes were calculated by multiplying the average reported spill volume with the minimum and maximum failure probability. Insufficient cementing (irrespective of the fluid) appears to be the main reason for the occurrence of failures, followed by oil-based fluids released due to leaking connectivity. Blowouts are the least frequent reason for failures; however, the associated average spill volume is the highest of all the studied mechanisms. Leaking connectivity and corroding well casing are the contamination pathways that result in the least fluid spilled. Furthermore, O'Maloney et al. (2017) looked into spill frequencies and volumes relating to the type of fluid for different US member states. They found that the main fluids of concern are UO\&G-related wastewater, crude oil, fracturing fluid, and drill waste. While crude oil is responsible for the highest frequency of spills, it has the second lowest related spill volume. Fracturing fluid has the lowest spill frequency but the highest spill volume. Patterson et al. (2017) mainly studied the US spill rates related to the well life and their causes. 2-16\% of wells report yearly spills, and 75-94\% of spills occur in the first 3 years of well life. Storage and pipeline transport were responsible for $50 \%$ of the reported spills.

During wastewater production, most of the injected fracturing fluid (92-96\%) remains in the subsurface formation (Kondash et al. 2017). Most of this water resides in the shale matrix, and only a small portion goes into surrounding fractures (O'Malley et al. 2015). The chemical fate of the UO\&G-related chemicals in the water system depends on their physicochemical characteristics and the circumstances in the matrix. For inorganics $\mathrm{pH}$, oxidation state, presence of iron oxides, soil organic 
matter, cation exchange capacity, and major ion chemistry are important. Their transport is governed by physical flow processes (advection and dispersion), sorption, and precipitation (USEPA 2015). Effects and impacts of organic substances may be altered by chemical degradation and other loss processes, e.g., sorption, oxidation, volatilization, etc. (USEPA 2015; Escher and Schwarzenbach 2002; Schnoor 1996). Some parameters are especially important when looking into chemical fate and transport in water systems. The $n$-octanol-water partition coefficient $\left(\log \mathrm{K}_{\mathrm{ow}}\right)$ relates to the accumulation in biological organisms and sorption to organic matrices as expressed by the soil organic carbon-water partition coefficient $\left(\mathrm{K}_{\mathrm{oc}}\right)$. Degradation half-lives describe the persistence of the chemicals and their susceptibility to (bio) degradation. Furthermore Henry's law constant describes volatilization. Again, databases are available that list or estimate these parameters such as EPISUITE, SPARC, or OECD's eChemPortal. For predicted parameters inorganic compounds fall outside the estimation domain (Gouin et al. 2004), and estimations might be inaccurate.

Current conceptual box models such as QWASI (Mackay et al. 2014) or SIMPLEBOX (Hollander et al. 2016) describe chemical fate in surface waters or shallow groundwater. Surface exposures can be modeled, but they do not take into account specific routes involved in UO\&G operations. As described above, UO\&Grelated exposures can originate from multiple sources, making it important to consider all the different exposure paths. Furthermore, a chemical deep underground will be subjected to high temperature (up to $200^{\circ} \mathrm{C}$ ), high pressure (above $10 \mathrm{MPa}$ ), and high salinity (TDS: $100,000-300,000 \mathrm{mg} / \mathrm{L}$ ), which might alter chemical behavior (Kahrilas et al. 2016). Increasing temperatures generally lead to higher solubility and reduced sorption (Huang 1980; Mackay 1980). Higher temperatures will also affect the degradation rate and up to a maximum temperature reduce half-lives (Klein 1989). There is not much information on chemical behavior under these conditions, except for glutaraldehyde (GA; Kahrilas et al. 2014, 2016). Kahrilas et al. (2016) found for this one chemical that the main conditions impacting chemical fate are temperature, $\mathrm{pH}$, and salinity, whereas pressure was not found to be important. High temperatures and/or alkaline $\mathrm{pH}$ caused GA to rapidly autopolymerize and eventually precipitate, whereas high salinity inhibited GA transformation.

\section{Discussion and Conclusion}

\subsection{Reducing Risk by Adequate Wastewater Management and Technological Innovation}

Wastewater management is a critical stage of the water life cycle of UO\&G production that can lead to environmental contamination (Camarillo et al. 2016; Kondash et al. 2017). Therefore, proper management is crucial in order to reduce the risks associated with UO\&G operations. Wastewater in the USA is typically 
made up of 4-8\% of injected fracturing fluid and $92-96 \%$ of naturally occurring formation brines, whereby $20-50 \%$ of the total produced wastewater is generated during the first 6 months of an active well (Kondash et al. 2017). Waste from drilling and fracking operations is typically stored in open air impoundments or in closed containers, to either be recycled for reuse or to be disposed via thermal treatment (incineration, pyrolysis, gasification), bioremediation, composting, or deep-well injection (Zoveidavianpoor et al. 2012; Boschee 2014; Camarillo et al. 2016; Butkovskyi et al. 2017). Wastewater management plans depend on regulations, cost, technology performance, location, and disposal alternatives (Gregory et al. 2011). Reinjection options are the cheapest and therefore also the most used management possibility, depending on a state's regulations (Clark and Veil 2009). However, due to the small number of adequate disposal wells in the USA and increasing stress on water availability in some areas, the need for wastewater reuse becomes more urgent. Consequently, the need for adequate treatment facilities gains importance, although the treatment technologies are challenged by the high salt content. Treated wastewater could be applied to roads for deicing and dustsuppression purposes (Warner et al. 2013a). Camarillo et al. (2016) and Butkovskyi et al. (2017) thoroughly describe the problems encountered related to wastewater treatment and possible solutions. More technological advancements are needed in wastewater treatment in order to promote reuse through efficient contaminant removal and cost reduction (Butkovskyi et al. 2017). Moreover, geotextiles and geosynthetics can be used at drilling sites to control surface failure probabilities and contamination effects, after spills have occurred (ter Heege et al. 2014). These are permeable fabrics, which are able to separate, filter, reinforce, protect, and drain wastewater from the surrounding environment. These products are readily available, but their use is not widespread (ter Heege et al. 2014). Underground leaks can be controlled by minimizing upward migration of contaminants, by keeping a minimum distance of $1.6 \mathrm{~km}$ between the bottom of the aquifer and the horizontal drill line (US EPA 2015).

\subsection{Identified Knowledge Gaps and Uncertainties}

There are several knowledge gaps and uncertainties that have been identified relating to the lack of evidence-based research, monitoring guidelines, available information on compounds, environmental fate models, and legislation. The number of publications that chemically characterize UO\&G-related water systems is limited. Most of the studies focus on shale gas in the USA and only a select few on coal-bed methane and tight sand gas. There is also limited research on chemical risk assessment of conventional oil and gas recovery (Alley et al. 2011; Thacker et al. 2015; Afenyo et al. 2017). This is important for comparison reasons and would provide insight into whether the risks related to unconventional activities are in fact higher than those related to conventional activities. Chemical characterization studies of UO\&G-related waters are generally based on target screening and do 
not consider the whole UO\&G-related water cycle (i.e., fracturing fluid, flowback/produced water, groundwater). Additionally, there are no databases on subsurface contaminants that may be mobilized during UO\&G operations, and the chemical registration of additives can be improved in FracFocus (USA). However, literature on subsurface contamination can be found. Registration of UO\&G fracturing fluid chemicals in the EU is still on a voluntary basis. Furthermore, the guidelines for water quality monitoring are not specified for adequate risk assessment for unconventional operations. As long as UO\&G-specific guidelines have not been set, an effect-directed assessment may provide a better insight into the risks to environmental or human health of UO\&G-related waters. Moreover, despite "good intentions" such as the Commission Recommendation 2014/70/EU, baseline monitoring is generally not ensured, and due to limited access to the deep underground and high costs, there is limited data available on deep underground failures, which makes it difficult to assess failure probabilities and ultimately the associated risk. In addition, only a small proportion of chemicals used in fracturing fluid has been evaluated as to their chronic toxicity, meaning that regulation and authorization of chemicals need to be updated. Moreover, there is limited information available on changes in chemical behavior under downhole conditions, which can be important when assessing the environmental fate of chemicals accidentally released into the deep underground. As a result the available environmental fate models do not allow to determine environmental fate in such a situation.

Also research in the field of risk assessments from a regulatory perspective shows important gaps. Environmental legislation is found at various institutional levels, including the international, regional (e.g., EU), national/federal, and subnational (e.g., state, supra-local, and local) levels. Neither at the international level nor at the US federal and the EU levels, specific regulations for UO\&G-related activities are in place to protect environmental and human health (Geraets and Reins 2016; Centner and Petetin 2015; Lange et al. 2013). Instead, both in the EU and the USA, there is a vast body of general legislation that is or can be applicable to UO\&G operations. However, at the US federal level, the oil and gas industry, mainly on the basis of the Energy Policy Act of 2005, benefits from exemptions from several major federal environmental statutes, including the Clean Air Act, the Clean Water Act, and the Safe Drinking Water Act (Brady and Crannell 2012). As a result and despite attempts of the US Congress to pass the Fracturing Responsibility and Awareness of Chemicals Act in 2013, operators seeking to conduct hydraulic fracturing are excluded from permitting well construction and chemical disclosure rules at the federal level (Grant 2016). Thus, most relevant regulation of UO\&G activities in the USA is to be found at the state level (Brady and Crannell 2012). Indeed, some states (e.g., Pennsylvania and Texas) have adopted general and/or specific regulations on UO\&G activities, including risk assessment, permitting systems, rules aiming at groundwater protection, requirements for drilling, well construction (e.g., casing, cementing) and well control, monitoring, and reporting arrangements, as well as obligations to disclose information about chemicals used during the fracturing process (Polishchuk 2017; Grant 2016; Roberson 2012). 
These regulations can be considered explicit, detailed, and well developed, albeit in some cases unclear and poorly disclosed (Polishchuk 2017).

At the EU level, the current legal framework governing UO\&G activities mainly consists of general environmental principles, directives, and regulations (Vos 2014). Key environmental principles, listed in Article 191(2) of the Treaty on the Functioning of the European Union, are to be at the basis of the environmental legislation and policies of the EU and its member states; these are the precautionary principle (Reins 2014a), the prevention principle (Fleming and Reins 2016), the principle that environmental harm should be rectified at source, and the polluter pays principle. Relevant directives and regulations are, inter alia, the Environmental Impact Assessment Directive (2011/92/EU), the WFD, the GWD, the DWD, the Mining Waste Directive (2006/21/EC), the Hydrocarbons Directive (94/22/EC), and the REACH Regulation and the Biocidal Products Regulation (Polishchuk 2017; Kevelam 2015; Vos 2014). However, REACH and the Biocidal Products Regulation provide specific risk assessments, but not all relevant substances are assessed, whereas other directives have included risk assessments as part of a licensing procedure or the environmental impact assessment, but these have not specifically been designed for assessing the risks related to the different stages of UO\&G operations. Indeed, the European Commission has issued UO\&G-tailored recommendations (Commission Recommendation 2014/70/EU), providing minimum principles or guidelines regarding, inter alia, strategic planning and assessing environmental impacts, baseline studies, installation design and construction, operational aspects, and monitoring. However, apart from its non-binding nature, it remains uncertain whether these recommendations will be effective in increasing uniformity and environmental/human health protection. At the point of, for instance, risk assessment it only refers to the general EU legislation mentioned above. At other points, this recommendation provides more tailored provisions, but these are still very generally formulated, leaving much room for interpretation. Nonetheless, formulated as an invitation to member states, the Recommendation should also be seen as an important step in the development of a more effective regulation of $\mathrm{UO} \& \mathrm{G}$ activities in the EU.

Lastly, although there is a large body of literature about EU environmental principles, directives, and regulations in general, there is hardly any literature to be found applying these to UO\&G activities (Vos 2014). Also at the level of the member states, specific UO\&G regulations are mostly absent (e.g., the Netherlands; Kevelam 2015; Brans and Van den Brink 2014) or in a very early and rudimentary stage of development (e.g., Poland; Polishchuk 2017; Atkins 2013), which means that $\mathrm{UO} \& \mathrm{G}$ activities are mostly regulated through general environmental, planning, and mining legislation. Moreover, legal literature on dealing with known and uncertain risks does not focus specifically on UO\&G activities but mostly on uncertain risks from an economic and governance perspective (Randall 2011) or from a general liability perspective or on specific aspects such as contract law (De Jong 2013, 2016; Pereira et al. 2016). 


\subsection{Implications for Risk Assessment and Legislation}

EU and member states" "UO\&G regimes" can be considered highly fragmented and at some points unsuitable and/or incomplete, particularly when it comes to regulating and monitoring the environmental risks of substances used in fracturing fluids or transformation products (Reins 2014b; also see Sects. 2.3 and 3). Therefore, further regulations should be implemented after the development of a better understanding of environmental risks related to UO\&G operations (Gordalla et al. 2013; Reins 2017). For these regulations, the introduction of the provision of mandatory location-specific and phase-specific risk assessments by potential hydraulic fracturing operators is recommended as a prerequisite for a permission to conduct UO\&G activities. In the UK, such a system already exists (Prpich et al. 2016). In this respect, a physics-based approach to detect and evaluate the possible risks for groundwater contamination, such as characterization of the system and migration pathways, could be implemented and used to compare risks between different sites to choose from (Lange et al. 2013). A spatial analysis method, mapping and quantifying the environment and population at risk, could provide further insight for risk assessment (Meng 2015). Changing industrial practices have the potential to modify behavior and fate of the compounds involved and should be considered (Goldstein et al. 2014). An evaluation of the risks for every stage of the hydraulic fracturing life cycle would allow for the prioritization and development of adequate management plans (Torres et al. 2016). Also social acceptance and perceptions from involved groups should be considered (Torres et al. 2016). The political decisions on unconventional drillings are not only based on scientific research but also influenced by the public, which means that the perception of risk by the general public is important for regulation. Familiarity with the process and trust are the two main factors influencing social beliefs (Wachinger et al. 2013). However, a recent study found that half of the people questioned were not familiar with the process of hydraulic fracturing, and the natural gas industry was considered an untrustworthy source of information (Theodori et al. 2014). A better long-term decision making procedure could be based on an iterative process where concerned parties come together to deliberate on risks, resulting in an improved transparency and understanding by the public on UO\&G-related processes and issues (Perry 2012). A holistic system of a transparent mandatory risk assessment could thus be implemented by considering site-specific data including results from previous risk assessments, social perception studies, and opinions of concerned parties (Torres et al. 2016). In addition to the actual risk assessment, it is important that risk assessment reports be up to standard. However, recently reviewed environmental impact statements produced between 1998 and 2008 were found to be of poor quality concerning environmental impact prediction and project decommissioning (Anifowose et al. 2016). Therefore, a systematic and independent reviewing of these reports is recommended in order to ensure good quality.

Rahm and Riha (2012) conclude that water quality requirements can be better ensured by weighing the need for energy development and for environmental health 
by imposing adequate regulation. On the one hand, energy supply and water quality could be considered equally important. In this case, a flexible regime considering interests from both parties would be adequate. On the other hand, focus could be primarily on environmental and human health protection. In this case a strict precautionary principle regime would be considered as an adequate regulation. There is a need for more data in order to evaluate the risk to the water system associated with hydraulic fracturing (Gagnon et al. 2015), and even if all the risks were identified, they can never be entirely eliminated. Such a regulation would require operators to conduct research in order to address the uncertainties and knowledge gaps related to risks of UO\&G operations. Risk assessment and monitoring can, moreover, be a rich source for developing environmental fate models and updating regulative and authorizations systems, which may be at the basis of UO\&G-specific (legal) guidelines for (ground)water quality monitoring.

\subsection{Conclusions and Way Forward}

We have identified a number of uncertainties and knowledge gaps in this paper. There is a need for more chemical-based risk assessment, especially on other types of UO\&G than shale gas, and in other countries than the USA. This is important for comparative reasons and ultimately for more effective regulation of UO\&G operations and the ongoing updating of authorization systems. More research is also needed to verify the applicability of current environmental fate models to UO\&Grelated risk scenarios. Due to the lack of detailed UO\&G-specific guidelines for monitoring, an effect-based monitoring may be implemented in relevant legislation to efficiently detect adverse effects to the surface water and groundwater systems. In view of the limited chronic toxicity data for UO\&G-related chemicals, an update of regulation and authorization systems is required. The introduction of a system based on mandatory, location-specific, and phase-specific risk assessments for permissions is recommended, with a holistic approach to risk assessment, including site-specific data, previous risk assessment data, and social risk perception. Additionally, systematic and independent reviewing of risk assessment reports is encouraged to ensure a well-founded quality of information. There is no specific UO\&G regulation on the federal US level and EU level but rather general legislation that is partly applicable to UO\&G operations. More specific UO\&G-tailored regulation could, however, be more effective in increasing both uniformity in practices and environmental/human health protection. Lastly, in view of the uncertainties related to $\mathrm{UO} \& \mathrm{G}$ risks, the precautionary principle may be given a more central role in $\mathrm{UO} \& \mathrm{G}$ regulation. 


\section{Summary}

The present study identifies uncertainties and knowledge gaps of chemical risk assessment related to unconventional drillings, and proposes adaptations. A discussion is provided demonstrating that chemical risk assessment in the context of unconventional oil and gas (UO\&G) activities differs from conventional chemical risk assessment, and this has implications for existing legislation. A suspect list of 1386 chemicals that might be expected in the UO\&G water samples was drafted. The list can be used for LC-HRMS suspect screening. An overview of reported concentrations of substances in UO\&G-related water is presented. Most information relates to shale gas operations, followed by coal-bed methane while only little is available for tight gas and conventional gas. The limited research on conventional oil and gas recovery hampers a comparative assessment of risks related to unconventional activities and those related to conventional activities. No study analyzed the whole cycle from fracturing fluid, flowback and produced water, and surfaceand groundwater. In the majority of studies target screening has been used, probably missing contaminants of concern. Almost half of the organic compounds analyzed in surface water and groundwater exceed the threshold of toxicological concern values, so further risk assessment is needed and risks cannot be waived. Specific exposure scenarios towards groundwater aquifers do not exist for UO\&G related activities. Human errors in various stages of the life cycle of UO\&G production play an important role in the exposure. Neither at the international level nor at the US federal and the EU levels, specific regulations for UO\&G related activities are in place to protect environmental and human health. UO\&G activities are mostly regulated through general environmental, planning, and mining legislation.

Acknowledgments This work is part of the research program "Shale Gas \& Water" with project number 859.14.001, which is financed by the Netherlands Organization for Scientific Research (NWO) and the drinking water companies Brabant Water, Oasen, and Waterleiding Maatschappij Limburg.

The authors declare that they have no conflict of interest.

\section{References}

Abualfaraj N, Gurian PL, Olson MS (2014) Characterization of Marcellus shale flowback water. Environ Eng Sci 31:514-524

ACGIH Worldwide (2013) Documentation of the TLVs and BEIs with other world wide occupational exposure values. Cincinnati

Afenyo M, Khan F, Veitch B, Yang M (2017) A probabilistic ecological risk model for Arctic marine oil spills. J Environ Chem Eng 5:1494-1503

Alawattegama SK, Kondratyuk T, Krynock R, Bricker M, Rutter JK, Bain DJ, Stolz JF (2015) Well water contamination in a rural community in southwestern Pennsylvania near unconventional shale gas extraction. J Environ Sci Health 50:516-528 
Alley B, Beebe A, Rodgers J, Castle JW (2011) Chemical and physical characterization of produced waters from conventional and unconventional fossil fuel resources. Chemosphere $85: 74-82$

Anifowose B, Lawler DM, Van der Horst D, Chapman L (2016) A systematic quality assessment of environmental impact statements in the oil and gas industry. Sci Total Environ 572:570-585

Annevelink MPJA, Meesters JAJ, Hendriks AJ (2016) Environmental contamination due to shale gas development. Sci Total Environ 550:431-438

Arini A, Cavallin JE, Berninger JP, Marfil-Vega R, Mills M, Villeneuve DL, Basu N (2016) In vivo and in vitro neurochemical-based assessments of wastewater effluents from the Maumee River area of concern. Environ Pollut 211:9-19

Atkins JP (2013) Hydraulic fracturing in Poland: a regulatory analysis. Wash Univ Glob Stud Law Rev 12:339-355

Baars AJ, Theelen RMC, Janssen PJCM, Hesse JM, Van Apeldoorn ME, Meijerink MCM, Verdam, L, Zeilmaker M (2001) Re-evaluation of human-toxicological maximum permissible risk levels. Report no. 711701025, National Institute of Public Health and the Environment, Bilthoven, The Netherlands

Backhaus T, Faust M (2012) Predictive environmental risk assessment of chemical mixtures: a conceptual framework. Environ Sci Technol 46:2564-2573

Barbot E, Vidic NS, Gregory KB, Vidic RD (2013) Spatial and temporal correlation of water quality parameters of produced waters from Devonian-age shale following hydraulic fracturing. Environ Sci Technol 47:2562-2569

Bletsou AA, Jeon J, Hollender J, Archontaki E, Thomaidis NS (2015) Targeted and non-targeted liquid chromatography-mass spectrometric workflows for identification of transformation products of emerging pollutants in the aquatic environment. Trends Anal Chem 66:32-44

Boschee P (2014) Produced and flowback water recycling and reuse: economics, limitations, and technology. Oil Gas Facil 3:16-22

Brack W, Dulio V, Ågerstrand M et al (2017) Towards the review of the European Union water framework management of chemical contamination in European surface water resources. Sci Total Environ 576:720-737

Brady WL, Crannell JP (2012) Hydraulic fracturing regulation in the United States: the LaissezFaire approach of the Federal Government and varying state regulations. Vermont J Environ Law 14:39-70

Brand W, de Jong CM, Van der Linden SC et al (2013) Trigger values for investigation of hormonal activity in drinking water and its sources using CALUX bioassays. Environ Int 55:109-118

Brans MC, Van den Brink KM (2014) Schaliegas in publiekrechtelijk kader - Lessen uit de praktijk van conventionele gaswinning. Milieu Recht 32:150-162

Burton TG, Rifai HS, Hildenbrand ZL, Carlton DD, Fontenot BE, Schug KA (2016) Elucidating hydraulic fracturing impacts on groundwater quality using a regional geospatial statistical modeling approach. Sci Total Environ 545:114-126

Butkovskyi A, Bruning H, Kools SA, Rijnaarts HH, Van Wezel AP (2017) Organic pollutants in shale gas flowback and produced waters: identification, potential ecological impact, and implications for treatment strategies. Environ Sci Technol 51:4740-4754

Camarillo MK, Domen JK, Stringfellow WT (2016) Physical-chemical evaluation of hydraulic fracturing chemicals in the context of produced water treatment. J Environ Manag 183:164-174

Centner TJ, O'Connell LK (2014) Unfinished business in the regulation of shale gas production in the United States. Sci Total Environ 476:359-367

Centner TJ, Petetin L (2015) Permitting program with best management practices for shale gas wells to safeguard public health. J Environ Manag 163:174-183

Chapman EC, Capo RC, Stewart BW, Kirby CS, Hammack RW, Schroeder KT, Edenborn HM (2012) Geochemical and strontium isotope characterization of produced waters from Marcellus shale natural gas extraction. Environ Sci Technol 46:3545-3553

Clark CE, Veil JA (2009) Produced water volumes and management practices in the United States. Argonne National Laboratory ANL/EVS/R-09-1. In: Prepared for the U.S. Department of 
Energy, National Energy Technology Laboratory, September, p 64. http://www.ead.anl.gov/ pub/dsp_detail.cfm?PubID $=2437$

COGC (2014) Colorado Oil and Gas Conservation Commission. Inspection./incident inquiry. http://cogcc.state.co.us/. Accessed 4 Jun 2014

Cuadrilla (2016) Cuadrilla resources ePortal. https://www.cuadrillaresourceseportal.com/

Dahm KG, Guerra KL, Xu P, Drewes JE (2011) Composite geochemical database for coalbed methane produced water quality in the Rocky mountain region. Environ Sci Technol 45:7655-7663

De Jong ER (2013) Regulating uncertain risks in an innovative society: a liability law perspective. In: Hilgendorf E, Günther JP (eds) Robotik und Recht Band I. Nomosverlag, Baden-Baden, pp 163-183

De Jong ER (2016) Voorzorgverplichtingen: over aansprakelijkheidsrechtelijke normstelling voor onzekere risico's. Dissertation, Boomjuridisch, Utrecht University

DeGraeve GM, Elder RG, Woods DC, Bergman HL (1982) Effect of naphthalene and benzene on fathead minnows and rainbow trout. Arch Environ Contam Toxicol 11:487-490

DHHS ATSDR (2010) Toxicological profile for Ethylbenzene. US Department of Health and Human Services Agency for Toxic substances and disease registry. http://www.atsdr.cdc.gov/ toxprofiles/tp110.pdf

ECHA (2017) European Chemicals Agency's regulated chemicals database. https://echa.europa. eu/information-on-chemicals/registered-substances. Accessed 6 Jul 2017

EFSA (2017) European food safety authority database. https:/www.efsa.europa.eu/en/data/chem ical-hazards-data. Accessed 5 Apr 2017

Elliott EG, Trinh P, Ma X, Leaderer BP, Ward MH, Deziel NC (2017) Unconventional oil and gas development and risk of childhood leukemia: assessing the evidence. Sci Total Environ 576:138-147

Escher B, Leusch F (2012) Bioanalytical tools in water quality assessment. IWA Publishing, London

Escher BI, Schwarzenbach RP (2002) Mechanistic studies on baseline toxicity and uncoupling of organic compounds as a basis for modeling effective membrane concentrations in aquatic organisms. Aquat Sci 64:20-35

Escher B, Allinson M, Altenburger R et al (2013) Benchmarking organic micropollutants in wastewater, recycled water and drinking water with in vitro bioassays. Environ Sci Technol 48:1940-1956

ExxonMobile (2016) ExxonMobile chemical disclosure registry. http://www.erdgassuche-indeutschland.de/hydraulic_fracturing/frac_massnahmen.html. Accessed 6 Nov 2016

Ferrar KJ, Michanowicz DR, Christen CL, Mulcahy N, Malone SL, Sharma RK (2013) Assessment of effluent contaminants from three facilities discharging marcellus shale wastewater to surface waters in pennsylvania. Environ Sci Technol 47:3472-3481

Ferrer I, Thurman EM (2015a) Analysis of hydraulic fracturing additives by LC/Q-TOF-MS. Anal Bioanal Chem 407:6417-6428

Ferrer I, Thurman EM (2015b) Chemical constituents and analytical approaches for hydraulic fracturing waters. Trends Environ Anal Chem 5:18-25

Fleming R, Reins L (2016) Shale gas extraction, precaution and prevention: a conversation on regulatory responses. Energy Res Soc Sci 20:131-141

Fontenot BE, Hunt LR, Hildenbrand ZL, Carlton DD Jr, Oka H, Walton JL, Osorio A, Bjorndal B, $\mathrm{Hu} \mathrm{QH}$, Schug KA (2013) An evaluation of water quality in private drinking water wells near natural gas extraction sites in the Barnett shale formation. Environ Sci Technol 47:10032-10040. https://doi.org/10.1021/es4011724

Gagnon GA, Krkosek W, Anderson L, McBean E, Mohseni M, Bazri M, Mauro I (2015) Impacts of hydraulic fracturing on water quality: a review of literature, regulatory frameworks and an analysis of information gaps. Environ Rev 24:122-131

Geraets D, Reins L (2016) The case of shale gas extraction regulation in light of CETA and TTIP: another example of the frackmentation of international law. Environ Liabil 24:16-25 
Goldstein BD, Brooks BW, Cohen SD et al (2014) The role of toxicological science in meeting the challenges and opportunities of hydraulic fracturing. Toxicol Sci 139:271-283

Gordalla BC, Ewers U, Frimmel FH (2013) Hydraulic fracturing: a toxicological threat for groundwater and drinking-water? Environ Earth Sci 70:3875-3893

Gouin T, Cousins I, Mackay D (2004) Comparison of two methods for obtaining degradation halflives. Chemosphere 56:531-535

Gramatica P (2007) Principles of QSAR models validation: internal and external. Mol Inf 26:694-107

Grant MF (2016) A critical assessment of the U.S. Environmental regulation of shale gas development - what can be learned from the U.S. experience? Edinburgh Law School working paper 2016/1

Grant CJ, Weimer AB, Marks NK et al (2015) Marcellus and mercury: assessing potential impacts of unconventional natural gas extraction on aquatic ecosystems in northwestern Pennsylvania. J Environ Sci Health 50:482-500

Gregory KB, Vidic RD, Dzombak DA (2011) Water management challenges associated with the production of shale gas by hydraulic fracturing. Elements 7:181-186

Gross SA, Avens HJ, Banducci AM, Sahmel J, Panko JM, Tvermoes BE (2013) Analysis of BTEX groundwater concentrations from surface spills associated with hydraulic fracturing operations. J Air Waste Manage Assoc 63:424-432

Harkness JS, Darrah TH, Warner NR et al (2017) The geochemistry of naturally occurring methane and saline groundwater in an area of unconventional shale gas development. Geochim Cosmochim Acta 208:302-334

Harris AE, Hopkinson L, Soeder DJ (2016) Developing monitoring plans to detect spills related to natural gas production. Environ Monit Assess 188:647

Hayes T (2009) Sampling and analysis of water streams associated with the development of Marcellus shale gas. Marcellus Shale Initiative Publications Database, 10

Hayes T, Severin BF (2012) Barnett and Appalachian Shale water management and reuse technologies. Final Report. RPSEA Contract 08122-05

Heilweil VM, Grieve PL, Hynek SA, Brantley SL, Solomon DK, Risser DW (2015) Stream measurements locate thermogenic methane fluxes in groundwater discharge in an area of shale-gas development. Environ Sci Technol 49:4057-4065

Hildenbrand ZL, Carlton Jr DD, Fontenot BE et al (2015) A comprehensive analysis of groundwater quality in the Barnett Shale region. Environ Sci Technol 49:8254-8262

Hladik ML, Focazio MJ, Engle M (2014) Discharges of produced waters from oil and gas extraction via wastewater treatment plants are sources of disinfection by-products to receiving streams. Sci Total Environ 466:1085-1093

Hoelzer K, Sumner AJ, Karatum O et al (2016) Indications of transformation products from hydraulic fracturing additives in shale-gas wastewater. Environ Sci Technol 50:8036-8048

Hogenboom AC, Van Leerdam JA, De Voogt P (2009) Accurate mass screening and identification of emerging contaminants in environmental samples by liquid chromatography-hybrid linear ion trap Orbitrap mass spectrometry. J Chromatogr A 1216:510-519

Hollander A, Schoorl M, Van de Meent D (2016) SimpleBox 4.0: improving the model while keeping it simple.... Chemosphere 148:99-107

Howarth RW, Ingraffea A, Engelder T (2011) Natural gas: should fracking stop? Nature 477:271-275

Huang PM (1980) Adsorption processes in soil. In: Hutzinger O (ed) The handbook of environmental chemistry, vol 2 Part A, Reactions and processes. Springer-Verlag, New York, pp $47-59$

Hug C, Ulrich N, Schulze T, Brack W, Krauss M (2014) Identification of novel micropollutants in wastewater by a combination of suspect and nontarget screening. Environ Pollut 184:25-32

IARC (2017) Monographs on the evaluation of the carcinogenic risk of chemicals to humans. International Agency for Research on Cancer, 1972-PRESENT. http://monographs.iarc.fr/ ENG/Classification/index.php. Accessed 5 Apr 2017 
IEA (2017) International Energy Agency's unconventional gas production database. https://www. iea.org/ugforum/ugd/

Jackson RB, Vengosh A, Darrah TH, Warner NR, Down A, Poreda RJ, Osborn SG, Zhao K, Karr JD (2013a) Increased stray gas abundance in a subset of drinking water wells near Marcellus shale gas extraction. Proc Natl Acad Sci 110:11250-11255

Jackson RE, Gorody AW, Mayer B, Roy JW, Ryan MC, Van Stempvoort DR (2013b) Groundwater protection and unconventional gas extraction: the critical need for field-based hydrogeological research. Ground Water 51:488-510

Kahrilas GA, Blotevogel J, Stewart PS, Borch T (2014) Biocides in hydraulic fracturing fluids: a critical review of their usage, mobility, degradation, and toxicity. Environ Sci Technol 49:16-32

Kahrilas GA, Blotevogel J, Corrin ER, Borch T (2016) Downhole transformation of the hydraulic fracturing fluid biocide glutaraldehyde: implications for flowback and produced water quality. Environ Sci Technol 50:11414-11423

Kassotis CD, Tillitt DE, Davis JW, Hormann AM, Nagel SC (2013) Estrogen and androgen receptor activities of hydraulic fracturing chemicals and surface and ground water in a drilling-dense region. Endocrinology 155:897-907

Kassotis CD, Klemp KC, Vu DC et al (2015) Endocrine-disrupting activity of hydraulic fracturing chemicals and adverse health outcomes after prenatal exposure in male mice. Endocrinology 156:4458-4473

Kassotis CD, Tillitt DE, Lin CH, McElroy JA, Nagel SC (2016a) Endocrine-disrupting chemicals and oil and natural gas operations: potential environmental contamination and recommendations to assess complex environmental mixtures. Environ Health Perspect 124:256-264

Kassotis CD, Bromfield JJ, Klemp KC et al (2016b) Adverse reproductive and developmental health outcomes following prenatal exposure to a hydraulic fracturing chemical mixture in female C57B1/6 mice. Endocrinology 157:3469-3348

Kevelam J (2015) De juridische bescherming van drinkwaterbronnen bij schaliegaswinning. Dissertation, Utrecht University

King GE (2012) Hydraulic fracturing 101: what every representative, environmentalist, regulator, reporter, investor, university researcher, neighbor and engineer should know about estimating frac risk and improving frac performance in unconventional gas and oil wells. In: Society of Petroleum Engineers Hydraulic Fracturing Technology Conference, Texas, pp 1-80

Klein W (1989) Mobility of environmental chemicals, including abiotic degradation. In: Bourdeau P, Haines JA, Klein W, Krishna Murti CR (eds) Ecotoxicology and climate: with special reference to hot and cold climates. Wiley, Chichester, pp 65-78

Kolkman A, Schriks M, Brand W et al (2013) Sample preparation for combined chemical analysis and in vitro bioassay application in water quality assessment. Environ Toxicol Pharmacol 36:1291-1303

Kondash AJ, Albright E, Vengosh A (2017) Quantity of flowback and produced waters from unconventional oil and gas exploration. Sci Total Environ 574:314-321

Krauss M, Singer H, Hollender J (2010) LC-high resolution MS in environmental analysis: from target screening to the identification of unknowns. Anal Bioanal Chem 397:943-951

Kroes R, Kleiner J, Renwick A (2005) The threshold of toxicological concern concept in risk assessment. Toxicol Sci 86:226-230

Kühne R, Ebert RU, von der Ohe PC, Ulrich N, Brack W, Schüürmann G (2013) Read-across prediction of the acute toxicity of organic compounds toward the water flea daphnia magna. Mol Inf 32:108-120

Lange T, Sauter M, Heitfeld M et al (2013) Hydraulic fracturing in unconventional gas reservoirs: risks in the geological system part 1. Environ Earth Sci 70:3839-3853

Lee Y, von Gunten U (2012) Quantitative structure - activity relationships (QSARs) for the transformation of organic micropollutants during oxidative water treatment. Water Res 46:6177-6195

Leendert V, Van Langenhove H, Demeestere K (2015) Trends in liquid chromatography coupled to high-resolution mass spectrometry for multi-residue analysis of organic micropollutants in aquatic environments. Trends Anal Chem 67:192-208 
Lester Y, Ferrer I, Thurman EM, Sitterley KA, Korak JA, Aiken G, Linden KG (2015) Characterization of hydraulic fracturing flowback water in Colorado: implications for water treatment. Sci Total Environ 512:637-644

Leusch FD, Neale PA, Hebert A, Scheurer M, Schriks MC (2017) Analysis of the sensitivity of in vitro bioassays for androgenic, progestagenic, glucocorticoid, thyroid and estrogenic activity: suitability for drinking and environmental waters. Environ Int 99:120-130

Mackay D (1980) Solubility, partition coefficients, volatility, and evaporation rates. In: Hutzinger $\mathrm{O}$ (ed) A handbook of environmental chemistry, vol 1. Part A Reactions and Processes. Springer-Verlag, New York, pp 31-45

Mackay D, Hughes L, Powell DE, Kim J (2014) An updated Quantitative Water Air Sediment Interaction (QWASI) model for evaluating chemical fate and input parameter sensitivities in aquatic systems: application to D5 (decamethylcyclopentasiloxane) and PCB-180 in two lakes. Chemosphere 111:359-365

Maguire-Boyle SJ, Barron AR (2014) Organic compounds in produced waters from shale gas wells. Environ Sci Processes Impacts 16:2237-2248

Malaj E, Peter C, Grote M, Kühne R et al (2014) Organic chemicals jeopardize the health of freshwater ecosystems on the continental scale. Proc Natl Acad Sci 111:9549-9554

Maloney KO, Baruch-Mordo S, Patterson LA, Nicot JP, Entrekin SA, Fargione JE et al (2017) Unconventional oil and gas spills: materials, volumes, and risks to surface waters in four states of the US. Sci Total Environ 581:369-377

Maule AL, Makey CM, Benson EB, Burrows IJ, Scammell MK (2013) Disclosure of hydraulic fracturing fluid chemical additives: analysis of regulations. New Solut 23:167-187

Mellert W, Deckardt K, Kaufmann W, Van Ravenzwaay B (2007) Ethylbenzene: 4-and 13-week rat oral toxicity. Arch Toxicol 81:361-370

Meng Q (2015) Spatial analysis of environment and population at risk of natural gas fracking in the state of Pennsylvania, USA. Sci Total Environ 515:198-206

Mons MN, Heringa MB, Van Genderen J (2013) Use of the Threshold of Toxicological Concern (TTC) approach for deriving target values for drinking water contaminants. Water Res 47:1666-1678

Montgomery CT, Smith MB (2010) Hydraulic fracturing: history of an enduring technology. J Pet Technol 62:26

Müller A, Schulz W, Ruck WK, Weber WH (2011) A new approach to data evaluation in the non-target screening of organic trace substances in water analysis. Chemosphere 85:1211-1219

Murk AJ, Legler J, Van Lipzig MM et al (2002) Detection of estrogenic potency in wastewater and surface water with three in vitro bioassays. Environ Toxicol Chem 21:16-23

NAM (2016) Nederlandse aardoliematschappij chemical disclosure database. http://www.nam.nl/ nl/downloads/information-fracking.html. Accessed 12 Jun 2016

Navarro HA, Price CJ, Marr MC, Myers CB, Heindel JJ (1992) Final report on the developmental toxicity of naphthalene (CAS No. 91-20-3) in New Zealand white rabbits on gestational days 6 through 19. Chemistry and Life Sciences Research Triangle Institute. NTIS Technical Report No PB-92-219831, Durham. https://www.osti.gov/scitech/biblio/6992005

Nelson J, Bishay F, Van Roodselaar A, Ikonomou M, Law FC (2007) The use of in vitro bioassays to quantify endocrine disrupting chemicals in municipal wastewater treatment plant effluents. Sci Total Environ 374:80-90

NGS (2016) Natural gas from shale hydraulic fracturing fluid and additive component transparency service. http://www.ngsfacts.org/findawell/. Accessed 6 Oct 2016

NRC (2014) National response centre. http://www.nrc.uscg.mil/. Accessed 4 Jun 2014

NTP (1990) Toxicology and carcinogenesis studies of Toluene (CAS No. 108-88-3) in F344/N Rats and B6C3F1 Mice (Inhalation Studies). National Toxicology Program Technical Report Series 371:1. https://ntp.niehs.nih.gov/ntp/htdocs/lt_rpts/tr371.pdf

O'Malley D, Karra S, Currier RP, Makedonska N, Hyman JD, Viswanathan HS (2015) Where does water go during hydraulic fracturing? Ground Water 54:488-497

OCD (2014) State of Mexico oil conservation division. Lozing search. https://wwwapps.emnrd. state.nm.us/ocd/ocdpermitting/Data/Incidents/SpillsearchResults.aspx. Accessed 4 Jun 2014 
Olsson O, Weichgrebe D, Rosenwinkel KH (2013) Hydraulic fracturing wastewater in Germany: composition, treatment, concerns. Environ Earth Sci 70:3895-3906

OPPPW (2016) The polish exploration and production industry organization chemical disclosure database. http://www.opppw.pl/en/fracturing_fluid_composition/23. Accessed 6 Oct 2016

Orem W, Tatu C, Varonka M (2014) Organic substances in produced and formation water from unconventional natural gas extraction in coal and shale. Int J Coal Geol 126:20-31

Osborn SG, Vengosh A, Warner NR, Jackson RB (2011) Methane contamination of drinking water accompanying gas-well drilling and hydraulic fracturing. Proc Natl Acad Sci 108:8172-8176

PADEP (2014) Pennsylvania Department of Environmental Protection OC compliance. http://www. depreportingservices.state.pa.us/ReportServer/Pages/ReportViewer.aspx?/Oil_Gas/OG_Compli ance. Accessed 4 Jun 2014

Patterson LA, Konschnik KE, Wiseman H et al (2017) Unconventional oil and gas spills: risks, mitigation priorities, and state reporting requirements. Environ Sci Technol 51:2563-2573

Pereira E, Reins L, Zhang L, Costa H, Nace J (2016) Regulatory and contractual challenges for unconventional resources: an international perspective. UEF Energy Law Rev 1:1-38

Perry SL (2012) Environmental reviews and case studies: addressing the societal costs of unconventional oil and gas exploration and production: a framework for evaluating short-term, future, and cumulative risks and uncertainties of hydrofracking. Environ Pract 14:352-365

Polishchuk K (2017) Shale gas regulation in the USA, Poland and Ukraine: managing groundwater contamination risks. Dissertation, Utrecht University

Poulsen A, Chapman H, Leusch F, Escher B (2011) Application of bioanalytical tools for water quality assessment. Urban Water Security Research Alliance Technical Report No 41, Brisbane. https://www.researchgate.net/publication/267824499_Application_of_Bioanalytical_Tools_for_ Water_Quality_Assessment

Preston TM, Chesley-Preston TL (2015) Risk assessment of brine contamination to aquatic resources from energy development in glacial drift deposits: Williston Basin, USA. Sci Total Environ 508:534-545

Prpich G, Coulon F, Anthony EJ (2016) Review of the scientific evidence to support environmental risk assessment of shale gas development in the UK. Sci Total Environ 563:731-740

Rahm BG, Riha SJ (2012) Toward strategic management of shale gas development: regional, collective impacts on water resources. Environ Sci Pol 17:12-23

Randall A (2011) Risk and precaution. Cambridge University Press, Cambridge

Reemtsma T, Berger U, Arp HPH, Gallard H, Knepper TP, Neumann M, Quintana JB, Voogt PD (2016) Mind the Gap: Persistent and Mobile Organic Compounds: Water Contaminants that Slip Through. Environ Sci Technol 50:10308-10315

Reins L (2014a) European minimum principles for shale gas: preliminary insights with reference to the precautionary principle. Environ Liabil 22:16-27

Reins L (2014b) A research agenda for shale gas: challenges to a coherent regulation in the European Union. J Renew Energy Law Policy 5:167-171

Reins L (2017) Regulating shale gas: the challenge of coherent environmental and energy regulation. Edward Elgar Publishing, Cheltenham

Riedl J, Rotter S, Faetsch S, Schmitt-Jansen M, Altenburger R (2013) Proposal for applying a component-based mixture approach for ecotoxicological assessment of fracturing fluids. Environ Earth Sci 70:3907-3920

Roberson TW (2012) Environmental concerns of hydraulically fracturing a natural gas well. Utah Environ Law Rev 12:67-136

RRC (2014) Railroad commission of Texas loss report database. http://www.rrc.state.tx.us/oil-gas/ compliance-enforcement/h-8/

SCHER, SCENIHR, SCCS (2012) Opinion on the toxicity and assessment of chemical mixtures. Scientific committees on health and environmental risks (SCHER), Emerging and Newly Identified Health Risks (SCENIHR) and Consumer Safety (SCCS), European Commission. http://ec.europa.eu/health/scientific_committees/environmental_risks/docs/scher_o_155.pdf

Schnoor JL (1996) Environmental modeling: fate and transport of pollutants in water, air, and soil. Wiley, New York 
Scholz S, Sela E, Blaha L (2013) A European perspective on alternatives to animal testing for environmental hazard identification and risk assessment. Regul Toxicol Pharmacol 67:506-530

Schriks M, Heringa MB, Van der Kooi MM, de Voogt P, Van Wezel AP (2010a) Toxicological relevance of emerging contaminants for drinking water quality. Water Res 44:461-476

Schriks M, van Leerdam JA, Van der Linden SC, Van der Burg B, Van Wezel AP, de Voogt P (2010b) High-resolution mass spectrometric identification and quantification of glucocorticoid compounds in various wastewaters in The Netherlands. Environ Sci Technol 44:4766-4774

Schymanski EL, Singer HP, Longrée P et al (2014a) Strategies to characterize polar organic contamination in wastewater: exploring the capability of high resolution mass spectrometry. Environ Sci Technol 48:1811-1181

Schymanski EL, Jeon J, Gulde R, Fenner K, Ruff M, Singer HP, Hollender J (2014b) Identifying small molecules via high resolution mass spectrometry: communicating confidence. Environ Sci Technol 48:2097-2098

Schymanski EL, Singer HP, Slobodnik J (2015) Non-target screening with high-resolution mass spectrometry: critical review using a collaborative trial on water analysis. Anal Bioanal Chem 407:6237-6255

Shonkoff SB, Hays J, Finkel ML (2014) Environmental public health dimensions of shale and tight gas development. Environ Health Perspect 122:787

Sjerps RM, Vughs D, Van Leerdam JA, ter Laak TL, Van Wezel AP (2016) Data-driven prioritization of chemicals for various water types using suspect screening LC-HRMS. Water Res 93:254-264

Smit CE, Verbruggen EMJ (2012) Environmental risk limits for ethyl-benzene and tributylphosphate in water: a proposal for water quality standards in accordance with the Water Framework Directive. RIVM letter report 601714019. http://rivm.openrepository.com/rivm/ handle/10029/260138

Soeder DJ (2015) Adventures in groundwater monitoring: why has it been so difficult to obtain groundwater data near shale gas wells? Environ Geosci 22:139-148

Soeder DJ, Sharma S, Pckney N, Hopkinson L, Dilmore R, Kutchko B, Stewart B, Carter K, Hakala A, Capo R (2014) An approach for assessing engineering risk from shale gas wells in the United States. Int J Coal Geol 1226:4-19

Sophocleous M (2002) Interactions between groundwater and surface water: the state of the science. Hydrogeol J 10:52-67

Stringfellow WT, Domen JK, Camarillo MK, Sandelin WL, Borglin S (2014) Physical, chemical, and biological characteristics of compounds used in hydraulic fracturing. J Hazard Mater 275:37-54

Strong LC, Gould T, Kasinkas L, Sadowsky MJ, Aksan A, Wackett LP (2013) Biodegradation in waters from hydraulic fracturing: chemistry, microbiology, and engineering. J Environ Eng 140:B4013001

Tang JY, Taulis M, Edebeli J, Leusch FD, Jagals P, Jackson GP, Escher BI (2014) Chemical and bioanalytical assessment of coal seam gas associated water. Environ Chem 12:267-285

ter Heege JH, Griffioen J, Schavemaker YA, Boxem TAP (2014) Inventarisatie van technologieën en ontwikkelingen voor het verminderen van (rest) risico's bij schaliegaswinning, No. TNO-2014-R10919. TNO. https://repository.tudelft.nl/view/tno/uuid: d3f72f6d-c669-4e8a-b4aa-fa87e399bf00/

Thacker JB, Carlton DD, Hildenbrand ZL, Kadjo AF, Schug KA (2015) Chemical analysis of wastewater from unconventional drilling operations. Water 7:1568-1579

Theodori GL, Luloff AE, Willits FK, Burnett DB (2014) Hydraulic fracturing and the management, disposal, and reuse of frac flowback waters: views from the public in the Marcellus Shale. Energy Res Soc Sci 2:66-74

Torres L, Yadav OP, Khan E (2016) A review on risk assessment techniques for hydraulic fracturing water and produced water management implemented in onshore unconventional oil and gas production. Sci Total Environ 539:478-493 
US EPA (2015) Assessment of the potential impacts of hydraulic fracturing for oil and gas on drinking water resources. Office of Research and Development, US Environmental Protection Agency, Washington

US EPA (2016) Hydraulic fracturing for oil and gas: impacts from the hydraulic fracturing water cycle on drinking water resources in the United States. Office of Research and Development, U.S. Environmental Protection Agency, Washington

US EPA Ecotox (2017) U.S. Environmental Protection Agency's Ecotox database. https://cfpub. epa.gov/ecotox. Accessed 6 Apr 2017

US EPA IRIS (2017) U.S. Environmental Protection Agency's integrated risk information system. https://www.epa.gov/iris. Accessed 6 Apr 2017

US Fracfocus (2016) https://fracfocus.org/chemical-use/chemicals-public-disclosure. Accessed 5 Feb 2016

Van Herwijnen R, Vos JH (2009) Environmental risk limits for benzene, C10-13 alkyl derivs (LAB). RIVM Report No 601782016. http://www.rivm.nl/dsresource? objectid=a837022c94e9-481e-8d32b6cd3104c826\&type $=$ org \&disposition $=$ inline

Van Wezel AP, Ter Laak TL, Fischer A, Bäuerlein PS, Munthe J, Posthuma L (2017) Mitigation options for chemicals of emerging concern in surface waters; operationalising solutionsfocused risk assessment. Environ Sci Water Res Technol 3:403-414

Venkatesan AK, Halden RU (2015) Effective strategies for monitoring and regulating chemical mixtures and contaminants sharing pathways of toxicity. Int $\mathrm{J}$ Environ Res Public Health 12:10549-10557

Vidic RD, Brantley SL, Vandenbossche JM, Yoxtheimer D, Abad JD (2013) Impact of shale gas development on regional water quality. Science 340:6134

Vos A (2014) Shale gas extraction: in line with the general (environmental) principles of Union and Dutch law? Dissertation, Utrecht University

Wachinger G, Renn O, Begg C, Kuhlicke C (2013) The risk perception paradox implications for governance and communication of natural hazards. Risk Anal 33:1049-1065

Warner NR, Christie CA, Jackson RB, Vengosh A (2013a) Impacts of shale gas wastewater disposal on water quality in western Pennsylvania. Environ Sci Technol 47:11849-11857

Warner NR, Kresse TM, Hays PD, Down A, Karr JD, Jackson RB, Vengosh A (2013b) Geochemical and isotopic variations in shallow groundwater in areas of the Fayetteville Shale development, north-central Arkansas. Appl Geochem 35:207-220

Webb E, Bushkin-Bedient S, Cheng A, Kassotis CD, Balise V, Nagel SC (2014) Developmental and reproductive effects of chemicals associated with unconventional oil and natural gas operations. Rev Environ Health 29:307-318

Werner AK, Vink S, Watt K, Jagals P (2015) Environmental health impacts of unconventional natural gas development: a review of the current strength of evidence. Sci Total Environ 505:1127-1141

Westerhoff P, Yoon Y, Snyder S, Wert E (2005) Fate of endocrine-disruptor, pharmaceutical, and personal care product chemicals during simulated drinking water treatment processes. Environ Sci Technol 39:6649-6663

Yost EE, Stanek J, DeWoskin RS, Burgoon LD (2016) Estimating the potential toxicity of chemicals associated with hydraulic fracturing operations using quantitative structure-activity relationship modeling. Environ Sci Technol 50:7732-7742

Zhang M, Wang Y, Wang Q, Yang J, Yang D, Liu J, Li J (2010) Involvement of mitochondriamediated apoptosis in ethylbenzene-induced renal toxicity in rat. Toxicol Sci 115:295-303

Ziemkiewicz PF, Quaranta JD, Darnell A, Wise R (2014) Exposure pathways related to shale gas development and procedures for reducing environmental and public risk. J Nat Gas Sci Eng $16: 77-84$

Zoveidavianpoor M, Samsuri A, Shadizadeh SR (2012) Overview of environmental management by drill cutting re-injection through hydraulic fracturing in upstream oil and gas industry. In: Curkovic S (ed) Sustainable development - authoritative and leading edge content for environmental management. InTech. https:/www.intechopen.com/books/sustainable-develop ment-authoritative-and-leading-edge-content-for-environmental-management/overview-ofenvironmental-management-by-drill-cutting-re-injection-through-hydraulic-fracturing-in-u 